\title{
Coelenterazine-Dependent Luciferases as a Powerful Analytical Tool for Research and Biomedical Applications
}

\author{
Vasilisa V. Krasitskaya ${ }^{1}$, Eugenia E. Bashmakova ${ }^{1}$ and Ludmila A. Frank ${ }^{1,2, *}$ \\ 1 Institute of Biophysics SB RAS, Federal Research Center "Krasnoyarsk Science Center SB RAS", \\ 660036 Krasnoyarsk, Russia; vasilisa.krasitskaya@gmail.com (V.V.K.); jeyn_a@bk.ru (E.E.B.) \\ 2 School of Fundamental Biology and Biotechnology, Siberian Federal University, 660041 Krasnoyarsk, Russia \\ * Correspondence: lfrank@yandex.ru
}

Received: 28 August 2020; Accepted: 7 October 2020; Published: 10 October 2020

\begin{abstract}
The functioning of bioluminescent systems in most of the known marine organisms is based on the oxidation reaction of the same substrate-coelenterazine (CTZ), catalyzed by luciferase. Despite the diversity in structures and the functioning mechanisms, these enzymes can be united into a common group called CTZ-dependent luciferases. Among these, there are two sharply different types of the system organization- $\mathrm{Ca}^{2+}$-regulated photoproteins and luciferases themselves that function in accordance with the classical enzyme-substrate kinetics. Along with deep and comprehensive fundamental research on these systems, approaches and methods of their practical use as highly sensitive reporters in analytics have been developed. The research aiming at the creation of artificial luciferases and synthetic CTZ analogues with new unique properties has led to the development of new experimental analytical methods based on them. The commercial availability of many ready-to-use assay systems based on CTZ-dependent luciferases is also important when choosing them by first-time-users. The development of analytical methods based on these bioluminescent systems is currently booming. The bioluminescent systems under consideration were successfully applied in various biological research areas, which confirms them to be a powerful analytical tool. In this review, we consider the main directions, results, and achievements in research involving these luciferases.
\end{abstract}

Keywords: bioluminescence; coelenterazine; luciferase; $\mathrm{Ca}^{2+}$-regulated photoprotein; analytical systems

\section{Introduction}

It would not be an exaggeration to say that most of the currently known luminous organisms are marine inhabitants. These are representatives of different taxa, with bioluminescent systems of various degrees of complexity, with different mechanisms of bioluminescent reactions. Noteworthy here is the fact that in most of these bioluminescent systems, the compounds with similar chemical structures containing imidazopyrazinone skeleton act as a substrate (luciferin). As such, coelenterazine (CTZ) is most deeply and frequently studied (Figure 1). The history of its discovery, information on occurrence, properties and reactions are presented in the book by O. Shimomura-recently reedited [1]. Bioluminescence reaction arises when luciferin is oxidized by the molecular oxygen catalyzed by a specific enzyme, luciferase (Luc). The CTZ-dependent luciferases are represented by two strictly different types-luciferases and photoproteins-whose bioluminescence is dependent on $\mathrm{Ca}^{2+}$ (the so-called $\mathrm{Ca}^{2+}$-regulated photoproteins, $\mathrm{PhP}$ ). The first ones catalyze $\mathrm{CTZ}$ oxidation in accord with the classical enzyme-substrate interaction yielding coelenteramide (CTM, the decarboxylated derivative of $\mathrm{CTZ}$ ), $\mathrm{CO}_{2}$, and a quantum of blue light (Figure 1a). Luciferases of many organisms are 
well studied, their cDNAs were cloned, and the recombinant analogues as well as many genetically modified variants with the new improved properties were obtained [2,3].

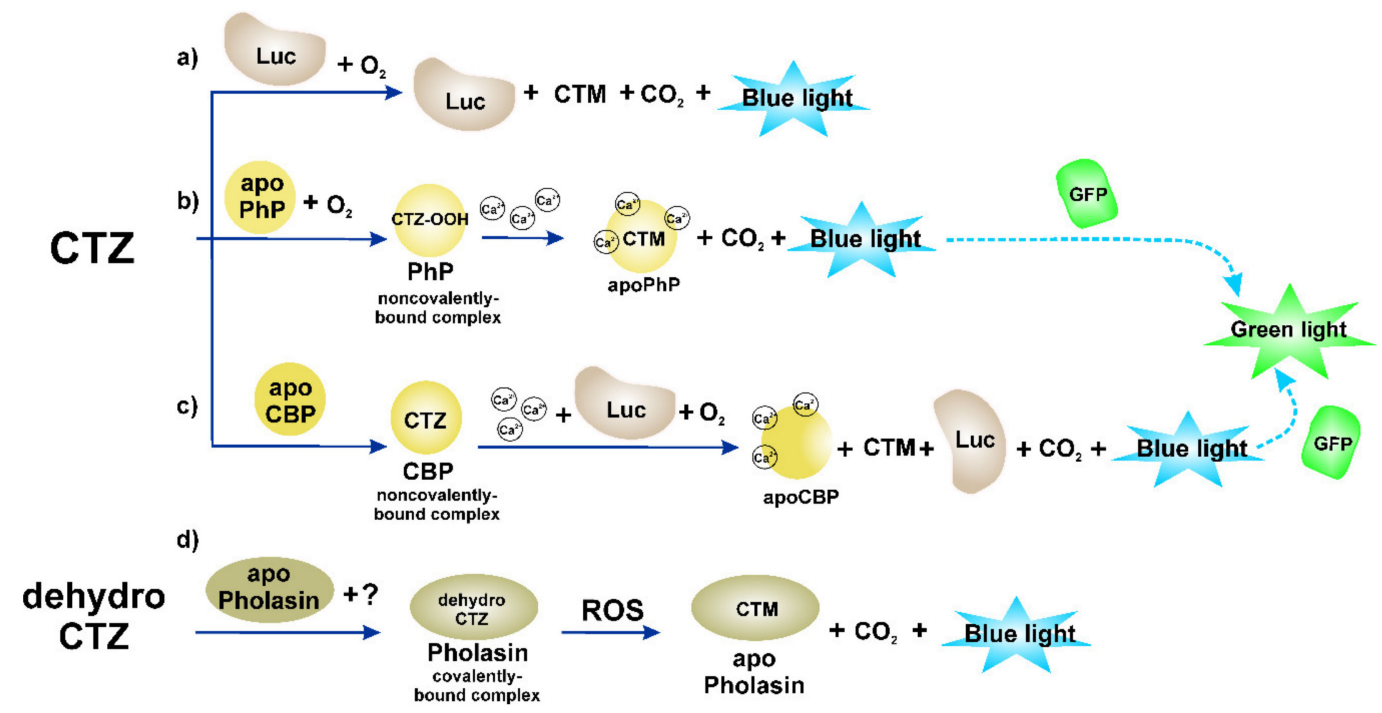

Figure 1. Variety of coelenterazine-dependent bioluminescent systems. (a-d) pathways of coelenterazine oxidation with the release of blue light, found in diverse organisms. Luc-luciferase; apoPhP_apophotoprotein; apoCBP_apo-coelenterazine binding protein; $\mathrm{CTZ}$ and $\mathrm{CTM}-$ coelenterazine and coelenteramide. Explanations are given in the text.

The $\mathrm{CTZ}$ oxidation by polypeptide apophotoprotein $(\mathrm{apoPhP})$ results in the formation of a stable complex comprising a protein and 2-hydroperoxycoelenterazine, which is actually a $\mathrm{Ca}^{2+}$-regulated photoprotein: bioluminescence occurs when calcium ions are bound (Figure 1b). The reaction products are: the complex of apoPhP with $\mathrm{CTM}$ and three $\mathrm{Ca}^{2+}, \mathrm{CO}_{2}$, and a quantum of blue light. So, in opposition to luciferases capable of making many turnovers, like the other enzymes, photoproteins produce the flash-type light only once. This suggests a fundamentally linear relationship between the protein amount and the light emitted. Being the in situ stable enzyme-substrate complexes, photoproteins have become of great academic interest-many proteins of the wild type (WT) and their mutant variants with altered bioluminescent properties were obtained, tertiary structures were determined, and the reaction mechanism was studied (e.g., [4]).

Of interest is the CTZ-dependent bioluminescent system found in a soft coral Renilla. Its particular feature is that coelenterazine in this animal is safety packed into the $\mathrm{Ca}^{2+}$-dependent coelenterazine-binding protein (CBP) cavity (Figure 1c) [5]. Its oxidation catalyzed by Renilla luciferase takes place when calcium ions are bound to the CBP [6]. In the in vitro experiments, the CBP was found to be of higher bioluminescence efficiency as a substrate compared to the free CTZ, possibly due to the formation of the CBP-luciferase complex [7].

As might be presumed, such a variety of bioluminescent systems in terms of organization characteristics is associated with the need to localize the substrate in such a way as to ensure its presence at the right time and in the right place. It is a general opinion that bioluminescence is a vital adaptation selected for in evolution. As the membrane permeability of CTZ is rather high [8], this substrate can be distributed throughout the whole organism. To keep the bioluminescence system in a "ready for action" mode, in case (a) luciferase and CTZ are stored separately in special secretory glands and are injected into the water, where they mix, forming a luminous cloud to deceive or scare away a predator (for example, systems of copepods Metridia or Gaussia). In case (b), luciferase and preoxydized luciferin are stable molecules of photoprotein ready to act under $\mathrm{Ca}^{2+}$ control, whose concentration rises by nerve stimulation (e.g., systems of coelenterates Aeqouria, Obelia, Beroe, and others). In case (c), CTZ luciferin is stored inside the CBP complex and becomes available 
for oxidation also under the $\mathrm{Ca}^{2+}$ control (e.g., the system of soft coral Renilla). It should be noted that owing to the stability of coelenterazine localized in CBP to spontaneous oxidation, this protein has been proved to be useful at analytical application of this form of substrate [9-11].

There is another kind of photoprotein utilizing CTZ derivative as a substrate with a bioluminescent system significantly different from that of $\mathrm{Ca}^{2+}$-regulated photoproteins (Figure 1d). It was found in glowing squids Watasenia scintillans and Symplectoteuthis oualaniensis (symplectin) and bivalve mollusk Pholas dactylus (pholasin). To date, the structure and functioning of the system are still poorly understood [12]. It is now classified as a reactive oxygen species (ROS)-sensitive photoproteins comprising a glycoapoprotein (shown for apo-pholasin only) with covalently bound (through sulfhydryl group of one of the cysteine residues) dehydrocoelenterazine (see Figure 2) for the light-emitting source. Nevertheless, poor knowledge about this bioluminescent system organization did not prevent the development of pholasin application as an indicator of ROS in various fields of research.
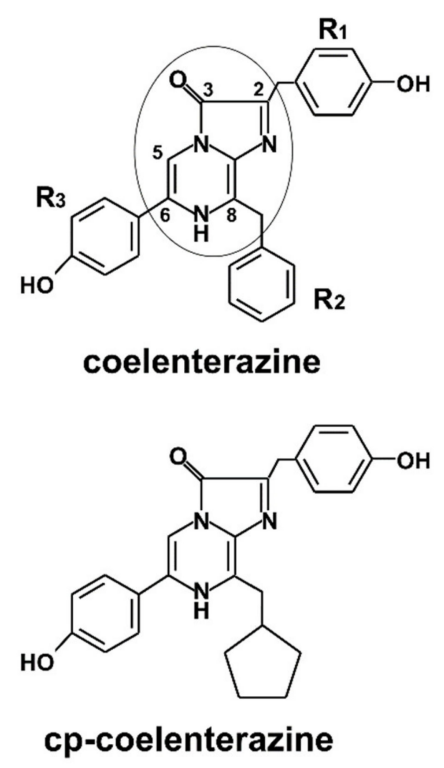
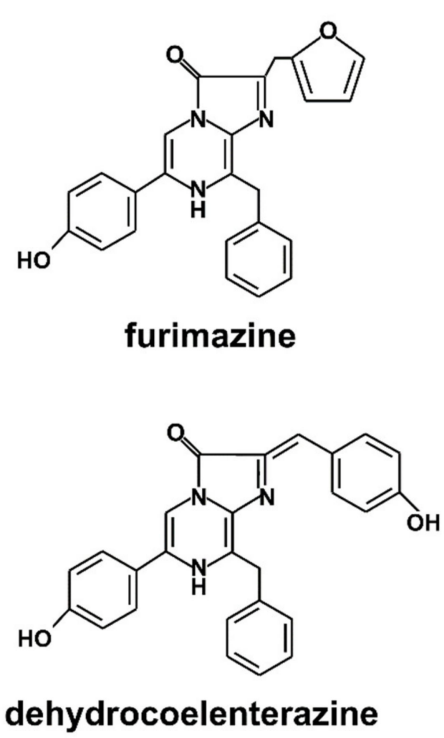

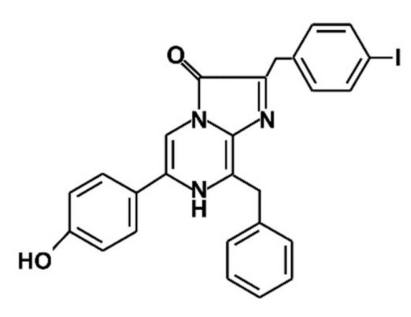

i-coelenterazine

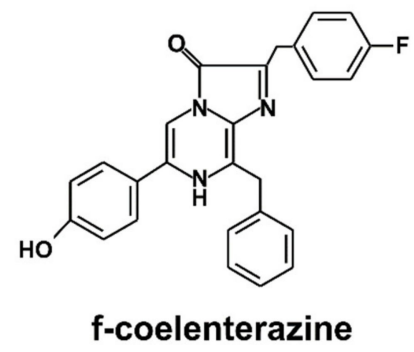

Figure 2. Chemical structures of coelenterazine and its analogues, mentioned in the review. Imidazopyrazinone core is shown in a circle.

All natural CTZ-dependent luciferases emit blue light with maxima at $460-480 \mathrm{~nm}$, apparently from the fact that the emitter is the same coelenteramide (or its close derivatives) in an excited state [1]. However, bioluminescence systems of many coelenterates contain the re-emitted molecule, whose fluorescence is shifted to the longer wavelength part of the spectrum with a maximum at $510 \mathrm{~nm}$. The green fluorescent protein (GFP) was discovered in 1961 in the jellyfish Aequorea aequorea [13] and then in other organisms (e.g., Clytia and Renilla). It was shown that the protein contains a chromophore inside the cylinder-shaped molecule, which is spontaneously formed from three amino acids (Ser65, Tyr66, and Gly67) [14,15]. So, light energy produced by CTZ-dependent luciferases is transferred to GFP resulting in the emission of green light. This process involves the mechanism of fluorescence (bioluminescence) resonance energy transfer (FRET/BRET) which underlies many modern research methods. After the cDNA of Aequorea GFP was cloned, and especially when it was successfully expressed in living organisms, its usefulness as an in vivo marker became apparent. The obvious importance of GFP for biomedical research activated the development of its recombinant forms with the improved properties (brighter, in different colors, etc.). Currently, the number of publications about this protein and its application is enormous. For a short account on the GFP chemistry, one can refer to the book by Shimomura [1].

The chemical structure of coelenterazine of natural type was determined, and its molecule was chemically synthesized in the mid-1960s-1970s [16]. The fundamental interest in the phenomenon of 
bioluminescence, its mechanism and the desire to change its characteristics resulted in the development of new synthetic variants of coelenterazine-like molecules. Some of these studies were aimed at searching those showing the improved bioluminescent signal. As of now, there are hundreds of CTZ variants which were synthesized and tested for applicability as the luciferase substrates. Of special interest were the CTZ variants providing alternative bioluminescence spectra and kinetics, being at the same time more stable under storage [17-20]. All coelenterazine analogues retain the molecule skeleton and differ in the structures of radicals R1-R3 (Figure 2). Therefore, the quantity of potentially useful synthetic CTZ variants is to be rather big, especially if it concerns the other luciferases. Many of CTZ variants demonstrate good perspectives for practical applications and are commercially available. The structures of some of them discussed hereafter are presented in Figure 2.

All CTZ-dependent luciferases known today, with a rare exception, are small, single-chain proteins, providing bright bioluminescence; their recombinant variants are easily available, and many of them are commercial products. These factors account for significant interest in their use as highly sensitive reporters in analytical systems for both in vitro and in vivo applications. Currently, there is a whole arsenal of luciferases as well as CTZ derivatives. These bioluminescent systems were successfully applied in various biological research areas, which confirms them to be a powerful analytical tool. It is impossible to cover a huge number of publications on this topic. In this review, we consider the main directions, results, and achievements in research involving these luciferases over the past 10-15 years.

\section{Analytical Application of $\mathrm{Ca}^{2+}$-Regulated Photoproteins}

The $\mathrm{Ca}^{2+}$-regulated photoproteins are single-chain globular proteins (MW of about $21 \mathrm{kDa}$ ) with a tightly but non-covalently bound molecule of pre-oxidized coelenterazine derivative-2-hydroperoxycoelenterazine in the protein internal cavity [21,22]. By virtue of this, their light emission is independent of the presence of molecular oxygen in the reaction mixture, this being one more feature of the $\mathrm{Ca}^{2+}$-regulated photoproteins that distinguishes them from other bioluminescent enzymes. Of all the known photoproteins, only aequorin from Aeqourea victoria and obelin from Obelia longissima, the most deeply studied ones, are used as reporters in analytics.

Bioluminescence reaction of this type of photoproteins is initiated by the binding of calcium ions to the EF-hand $\mathrm{Ca}^{2+}$-binding loops on the surface of a protein molecule, causing small conformational changes within the internal cavity of the protein. This disturbs the network of hydrogen bonds of the active center of the molecule and triggers the reaction of 2-hydroperoxycoelenterazine decarboxylation, yielding a mole of $\mathrm{CO}_{2}$ and the protein-bound product, coelenteramide, in an excited state. Its relaxation to the ground state is accompanied by light emission with $\lambda$ max at $465-495 \mathrm{~nm}$ [23].

Cloning of cDNAs encoding several photoproteins and their expression in bacterial cells, as well as effective activation of the recombinant apophotoproteins with a synthetic coelenterazine (under calcium-free conditions in the presence of $\mathrm{O}_{2}$ ) opened the way to obtaining almost unlimited amounts of the recombinant proteins as well as to producing different mutated and chimeric photoproteins. Many photoprotein mutants with altered characteristics such as higher thermostability and bioluminescence activity, different emission color, faster or slower bioluminescence kinetics, and modified calcium affinity $[3,4,24,25]$, as well as chimeric photoproteins genetically fused with different polypeptides, were produced. The diversity of photoprotein variants and synthetic coelenterazine analogues allow the development of novel bioluminescent assays or to improve characteristics of the already existing ones.

\section{1. $\mathrm{Ca}^{2+}$-Regulated Photoproteins as Indicators of Intracellular $\mathrm{Ca}^{2+}$}

The traditional application of $\mathrm{Ca}^{2+}$-regulated photoproteins is conditioned by their high specificity and sensitivity to calcium ions in a physiological concentration range (Figure 3) where they are used as a valuable probe for studying $\mathrm{Ca}^{2+}$ signaling [26]. Intracellular calcium ion signaling regulates numerous basic cellular processes including muscle contraction, release of mediators, synaptic plasticity, neuronal signal transmission, gene expression, proliferation, apoptosis, etc. Generally, calcium is often 
regarded as an agent affecting intracellular processes by changing its concentration-i.e., the level of free calcium, varying from $50 \mathrm{nM}$ to about $10 \mu \mathrm{M}$ at the peaks of a number of physiological signals [27]. Moreover, intracellular calcium signals regulate processes that operate over a wide time range, from neurotransmitter release at the microsecond scale to gene transcription, which lasts for minutes and hours. Thus, the time course, the amplitude, and, most notably, the local action site in well-defined cellular subcompartments are essential features of intracellular calcium signaling pathways.

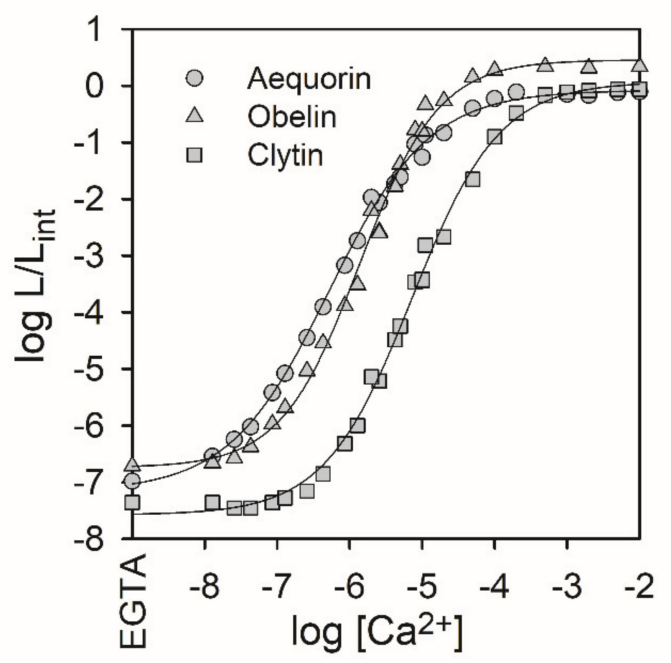

Figure 3. $\mathrm{Ca} 2+$ concentration-effect curves for recombinant photoproteins. L-light intensity at the particular $\mathrm{Ca} 2+$ concentration; Lint-total light intensity at saturating $\mathrm{Ca} 2+$ concentration.

Aequorin has been widely used as a gene-encoded $\mathrm{Ca}^{2+}$ indicator (GECI) in cells since it was cloned in 1985 and has been shown to be an effective tool to monitor intracellular $\left[\mathrm{Ca}^{2+}\right.$ ] (concentration of $\mathrm{Ca}^{2+}$ ) [28]. The emission of photoproteins is characterized by a high signal-to-noise ratio and a wide dynamic range. Bioluminescent recordings of calcium signals do not require external illumination, thus avoiding problems such as phototoxicity, photobleaching, autofluorescence, and undesirable stimulation of photobiological processes. Photoproteins have very low buffering capacity and are not toxic. Moreover, they can be modified to introduce specific targeting sequences providing selective routing of the photoprotein to a cell region of interest where local calcium transients need to be measured. Native-type aequorin is exclusively cytosolic, but the recombinant aequorin chimeras were constructed for targeting different intracellular compartments (nuclei, mitochondria, subplasma-membrane cytosol, endoplasmic/sarcoplasmic reticulum, Golgi apparatus, secretory vesicles, peroxisomes) [29,30].

The major efforts of researchers over the past 15 years have focused on expanding the arsenal of different photoprotein probes to cover specific requirements for visualization and quantitative estimation of the intracellular calcium signals. The main points here concerned: probe stability during in vivo measurements; the possibility to measure both low and high $\left[\mathrm{Ca}^{2+}\right]$ in single cells, in cytoplasm, and within defined intracellular compartments; to also measure both fast and slow $\left[\mathrm{Ca}^{2+}\right]$ fluxes; as well as the design of differently colored probes for multiplexing and red-colored probes for in vivo imaging.

Although recombinant photoproteins from various organisms are closely related, they differ in properties as intracellular calcium indicators with regard to $\mathrm{Ca}^{2+}$ concentration detection limit, $\mathrm{Mg}^{2+}$ sensitivity, and the rate of luminescence rise [31,32]. As a $\mathrm{Ca}^{2+}$-indicator, aequorin is more suitable at $\left[\mathrm{Ca}^{2+}\right]$ ranging from $10^{-7.5}$ to $10^{-4.5} \mathrm{M}$, while obelin-at $\left[\mathrm{Ca}^{2+}\right]$ between $10^{-6.5}$ and $10^{-3.5} \mathrm{M}[31]$. Clytin is the least sensitive to $\left[\mathrm{Ca}^{2+}\right]\left(\mathrm{K}_{\mathrm{D}}=500 \mathrm{nM}\right)$ [31]; berovin responds to changes in calcium concentration starting below $10^{-8} \mathrm{M}$ and reaches saturation at approximately $10^{-4} \mathrm{M}$ [33]. Sensitivity to calcium of mnemiopsin isoform 2 is lower compared to berovin and hydromedusan photoproteins and extends from $10^{-6}$ to $10^{-4.5} \mathrm{M}$ [34]. However, photoproteins of a wild type cannot be used as a probe for cellular organelles where $\left[\mathrm{Ca}^{2+}\right]$ is much higher-e.g., in the lumen of endoplasmic or 
sarcoplasmic reticulum (about $300-500 \mu \mathrm{M}$ ) or in mitochondria that can reach values of up to $100 \mu \mathrm{M}$. Numerous studies on photoprotein EF-hand motif have shown that calcium affinity of the protein can be changed. Different approaches have been used to perform modifications: specific point mutations of the $\mathrm{Ca}^{2+}$-binding sites, random mutagenesis and functional screening, replacement of the consensus sequence of the first $\mathrm{Ca}^{2+}$-binding site with a loop sequence belonging to other EF-hand $\mathrm{Ca}^{2+}$-binding proteins [4,25], or/and the usage of coelenterazine synthetic analogues [31]. The aequorin variant with a reduced $\mathrm{Ca}^{2+}$ affinity was produced and proved to be eminently suitable for measuring $\mathrm{Ca}^{2+}$ within cell compartments with high calcium concentration (endoplasmic reticulum, mitochondria, etc.) [35,36].

Several studies have been devoted to modifying the emission spectrum of photoproteins for making them applicable for in vivo imaging in deep tissue and for multiplexing screening. It is well known that animal tissue absorbs and scatters less light in the $600-900 \mathrm{~nm}$ range. Many aequorin and obelin variants with a broadened emission spectrum and various decay kinetics have been obtained by site-directed mutagenesis of the coelenterazine-binding cavity or by random mutagenesis $[4,25]$. The incorporation of non-natural amino acids into cystein-free aequorin in combination with various coelenterazine analogues allowed the production of aequorin emitting in the yellow region of the spectrum (maximum at $526 \mathrm{~nm}$ ) with long decay kinetics (half-life up to one minute) [37]. Another approach to obtain red-emitting photoproteins is to fuse them with fluorescent proteins or chemically attach them to fluorophores which act as BRET acceptors. For instance, aequorin has been conjugated to quantum-dot particles (CdSe/ZnS), resulting in the limited energy transfer with the presence of an emission peak around $540 \mathrm{~nm}$ [38]. The largest emission shift has been produced by fusing photoproteins with different variants of GFP (yellow, red, orange, etc.) (see, for review, [39]). The fusion of aequorin with a tandem dimer tdTomato generated "redquorin" characterized by high BRET efficiency, a major emission peak at $582 \mathrm{~nm}$, and a sensitivity high enough to detect spontaneous $\mathrm{Ca}^{2+}$ oscillations in single cells [40]. Aequorins, fused with GFP and RFP (red fluorescent protein [41]) and targeted to different subcellular locations have been successfully used to simultaneously and independently record the changes in $\mathrm{Ca}^{2+}$ concentrations in different subcellular compartments of the same cells—cytosol, mitochondria, endoplasmic reticulum (ER), and nucleus [42,43]. Of note is that in these studies, the mutant aequorin with a low affinity for $\mathrm{Ca}^{2+}$, as well as an artificial variant of coelenterazine, f-CTZ (Figure 2), were used for $\left[\mathrm{Ca}^{2+}\right]$ measurements in ER.

In the last 10 years, aequorin has been widely used as a $\mathrm{Ca}^{2+}$ indicator in a great variety of research: for studying the neural basis for Drosophila behavior [44-49]; exploring brain activity and visualizing $\mathrm{Ca}^{2+}$ signaling events that occur at the early stages of zebrafish development [44,50-54]; elucidating the $\mathrm{Ca}^{2+}$ response to biotic or abiotic stress in different plants [55-62] and yeast [63]; as well as for protozoa studies [64].

The extension of the arsenal of photoprotein probes has allowed to overcome some limitations concerning the application of photoproteins as probes for imaging $\mathrm{Ca}^{2+}$ fluxes in cell populations and in intact organisms as well as the measuring of $\left[\mathrm{Ca}^{2+}\right]$ in single cells, in the cytoplasm, and other cell compartments.

\section{2. $\mathrm{Ca}^{2+}$-Regulated Photoproteins as Effective Reporters for In Vitro Binding Assay}

At saturating concentration of $\mathrm{Ca}^{2+}$, the photoprotein-induced signal reaches its maximum, and overlaps several logs of concentration with a linear relationship between photoprotein amount and bioluminescence. A high quantum yield of the reaction, a virtual absence of the background bioluminescent signal, and a high sensitivity of modern photometers make the photoprotein detection down to attomole level possible [65]. Aequorin and obelin have been tested as reporters in various binding assays (Figure 4), such as ELISA-type, homogeneous, DNA-hybridization assay, or whole-cell sensing systems and have always shown a very low detection limit. Photoproteins have been shown to be inherently endowed with distinct advantages over absorbance, fluorescent, or radioactive reporters for use as labels in bioassays in vitro $[66,67]$. 


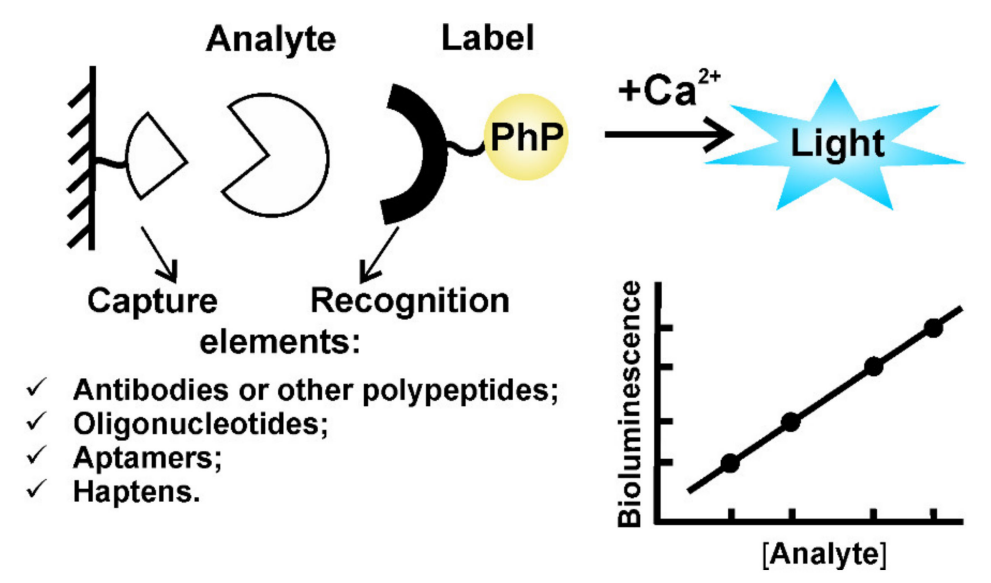

Figure 4. General scheme for bioluminescent solid-phase binding assay. Label is a chemically synthesized conjugate or genetically fused recognition element with a reporter molecule (PhP).

The detection of multiple biomarkers is a model trend that has proved to be effective in precise medicine for diagnosis and management of the disease. Mutated variants of aequorin and obelin as well as "semi-synthetic" aequorins (aequorins with introduced synthetic coelenterazine analogues) displaying altered bioluminescent properties (emission maxima and kinetics) expanded the analytical applications of photoproteins and made them amenable to simultaneous multianalyte detection in a single well.

With site-directed mutagenesis of the amino acids in the obelin active site applied, two stable and active obelin mutants of different color and bioluminescence reaction rates, suitable for multiplex analysis, were produced. The signals of the mutants obtained were shown to be effectively separated by using wideband optic filters and temporal resolution [68,69].

Obviously, this approach is especially suitable when the diagnosis is determined by the balance between a pair of hormones-e.g., gonadotrope hormones, luteinizing (hLH), and follicle-stimulating (hFSH) ones [69]—or when the hormone is present in two different forms—e.g., total and non-active immunoglobulin-bound (macro) prolactins [70]. The method is performed in high-throughput format and helps to overcome shortcomings of separate detection. Another type of analysis requiring the detection of two targets is the single nucleotide polymorphisms (SNP) genotyping, when two allele variants have to be elicited simultaneously. Based on the colored obelin reporters, the microassay of products of the primer extension reaction during the SNP identification was also developed [69]. The method was successfully applied to identify: four SNPs associated with the risk of hemostasis disorders [71] and three SNPs in gene of melanocortin-1 receptor (MC1R), associated with melanoma and non-melanoma skin cancer risk [72,73]. All results were in complete agreement with those obtained with the use of conventional RT-PCR techniques or Sanger sequences, but bioluminescent analysis is faster and cheaper.

"Semi-synthetic" aequorin variants with altered emission profiles and decay kinetics have been developed through a combination of site-specific mutations and application of synthetic coelenterazine analogues [74]. In the study, two aequorin mutant proteins were genetically conjugated to three pro-inflammatory cytokines (tumor necrosis factor alpha (TNF $\alpha$ ), interleukins IL6 and IL8). These fusion proteins were combined with $f-, i-$, and $c p$-coelenterazine, correspondingly (Figure 2). Fast bioluminescent signals from TNF $\alpha$ and IL8 were separated using bandpass filters with transmission peaks at 420 and $520 \mathrm{~nm}$ and measured within the first $6 \mathrm{~s}$. The only signal left was emitted from the IL6 and it was integrated during the next $19 \mathrm{~s}$. The validity of the assay was demonstrated by employing samples of artificial human serum, and the results were in agreement with those obtained by commercially available individual tests for each of the three cytokines.

The specificity of the binding assay is ensured by the combination of a reporter and biospecific molecule with affinity to a certain target (immunoglobulin, oligonucleotide, hapten, etc.). The molecules of the kind (biospecific bioluminescent labels) are usually obtained by chemical conjugation using 
different commercial reagents. To simplify and direct the synthesis, increase the conjugation yield, and to save the bioluminescence activity of photoproteins, several aequorin and obelin mutants carrying unique cysteine residues accessible for chemical modification were produced $[75,76]$.

One of the modern trends in binding analysis is the use of DNA/RNA aptamers as the recognition and binding elements that can successfully compete with monoclonal antibodies. Aptamers are short single-stranded oligonucleotides with a unique spatial structure that enables them to bind target molecules with high affinity and specificity. They offer several unique advantages: a possibility of chemical synthesis with minimal batch-to-batch variation, long shelf life, stability, and a large variety of available chemical modifications. Moreover, aptamers can be selected for any target, including toxic and non-immunogenic ones. Due to these useful features, aptamers are becoming increasingly popular as biospecific elements in a number of biomedical analytical systems (see, for review, [77]).

Several bioluminescence aptamer-based analytical systems have been developed and tested on a large number of clinical samples. Obelin chemically conjugated with specific DNA aptamers was applied as a label in sandwich-type solid-phase analysis of lung tumor elements in clinical plasma. The developed assay demonstrated good sensitivity of $91.5 \%$ and specificity of $75 \%(p<0.001)$ [78]. Analogous conjugate with (2'-F-Py) modified RNA aptamer to the multiple sclerosis (MS) related autoantibodies was used for detection of autoantibodies to myelin basic protein in sera samples from MS-diagnosed patients (91) and non-MS donors (81). A statistical analysis of the results showed a $63.7 \%$ sensitivity and a $94.2 \%$ specificity of the assay developed $[79,80]$. It is worth noting that the diagnosis and monitoring of MS requires sophisticated equipment and highly qualified personnel, and therefore, the development of an analytical approach is extremely relevant.

Using obelin as a reporter-a convenient technique-was developed for fast and easy monitoring of the DNA library enrichment and evaluating the affinity and specificity of the individual aptamers during the SELEX procedure [81]. The approach was applied for the selection and development of 2'-F-Py RNA aptamers to general and glycated hemoglobins-biomarkers of diabetes mellitus [82] and DNA aptamers to the cardiac troponin I-a specific biomarker for acute myocardial infarction [81].

In studies [83], the authors selected 2'-F-Py RNA aptamer to obelin and later used it for engineering structure-switching bi-modular aptamer constructs [84]. One aptamer module of the construct (antihemoglobin RNA aptamer) binds the analyte (hemoglobin) that causes structural reorganization of the second module making it able to bind the obelin molecule. The complex which is finally formed on the surface was detected by obelin bioluminescence. The proposed approach allows integrating the obelin reporter into the bioanalytical system without any chemical conjugation or engineering of the fused protein and might be further adjusted to the detection of other proteins simply by exchanging biospecific module.

Another way to connect the photoprotein molecule with biospecific polypeptide is to create a hybrid protein by fusing their gene. The approach has some benefits compared with chemical conjugation such as rapid bacterial production of homogeneous hybrids and easy purification using auxiliary affinity tags etc.

The fusion protein streptavidin to aequorin (STA-AQ) [85] and minimum-sized core streptavidin to obelin (SAV-OL) [86] were highly purified from the inclusion bodies in Escherichia coli (E. coli) cells and applied to a bioluminescent sandwich immunoassay. The obtained hybrids demonstrated several advantages over similar chemical conjugates: the easiest way of preparation; maximum retention of properties of the initial protein; and as a result, the higher sensitivity of the assay. The hybrid STA-AQ was tested in model immunoassay of $\alpha$-fetoprotein, which is a serological marker of liver cancer. The SAV-OL was applied as a reporter for detecting several targets such as cardiac markers (troponin I, troponin $\mathrm{T}$, myoglobin, creatine kinase $\mathrm{MB}$ ) and nucleic acids. The hybrids containing immunoglobulin-binding polypeptide $\mathrm{ZZ}$ with aequorin or that with obelin were obtained recently $[87,88]$. The aequorin-containing construction included two auxiliary polypeptides: signal peptide sequence of the outer membrane protein $\mathrm{A}(\mathrm{OmpA})$ and hexahistidine tag, providing the hybrid translocation into periplasmic space of the host $E$. coli cells and fast purification by metal-affinity chromatography. 
The obelin-containing hybrid was much simpler without any auxiliary polypeptides and was purified from the inclusion bodies in a manner similar to wild-type obelin [89]. It has been shown to be a highly sensitive label in various assays: detection of antibodies, assessment of their affinity, interaction with recombinant proteins, monitoring of SELEX, and affinity assessment of DNA (RNA) aptamers [88].

The described types of fusion proteins are universal probes: hybrids STA-AQ and SAV-OL are probes to any biotin-containing molecule, hybrids ZZ-AQ and ZZ-OL are the probes to IgG due to protein A affinity to Fc fragments. Of note is that photoproteins can be extended with a polypeptide from $\mathrm{N}$-terminus only, the extension of the $\mathrm{C}$-end terminus induces photoprotein instability [90]. This is a significant limitation in designing the photoprotein hybrids.

Nevertheless, methods, materials, and approaches developed in the field allow the production of unique multifunctional proteins with new useful properties applicable in different areas. For example, a genetic engineering approach was used to construct bioluminescent molecular switch created by the insertion of specific proteins into the aequorin structure [91-93]. The hybrids developed in these studies included an aequorin molecule split into two parts (1-47 and 48-189 amino acid fragments) that were linked by either glucose-binding protein (GBP), cyclic AMP (cAMP) binding receptor protein (CRP), or a sulfate-binding protein (SBP). Target binding to the corresponding specific protein allosterically transduces AEQ, turning the switch "on" (in the case of GBP or SBP sensors) or "off" (in the case of (AMP) and generating or quenching bioluminescence emission. The developed molecular bioluminescent switches were validated by performing targets detection in clinical and environmental samples demonstrating selectivity and reproducibility with appropriate detection limits.

\subsection{Analysis Based on the Aequorin Bioluminescence Inhibition}

Another type of the analyte detection assay is based on the inhibition of aequorin bioluminescence activity upon its interaction with a small molecule.

In the study [94], aequorin bioluminescence inhibition assay for quantification of hydroxylated polychlorinated biphenyls (OH-PCBs), toxic and persistent environmental contaminants, was developed. The OH-PCBs, as the authors suppose, become bound to the hydrophobic CTZ-binding cavity of aequorin due to similarity with the structure of CTZ causing a dose-dependent decrease in aequorin bioluminescence. The proposed assay was applied for determination of various OH-PCBs in biological and environmental samples without their preliminary treatment. Rahmani H. et al. developed aequorin-based inhibition assay for direct detection of dopamine in raw samples of blood serum or urine with a detection limit of $53 \mathrm{nM}$ [95]. The same research group proposed to use a aequorin bioluminescence system for superoxide anion detection [96]. The assay was based on decarboxylation of coelenterazine to coelenteramide by superoxide anion. The high superoxide anion concentration results in the increase in effective concentration of coelenterazine capable of charging the aequorin molecule. So, the bioluminescent signal of aequorin is inversely proportional to superoxide anion concentration with a linearity range between 4 and 40,000 pM and a detection limit of $1.2 \mathrm{pM}$.

One of the advantages of bioluminescence inhibition assay is the lack of aequorin modification step as it is both recognition and signal generating molecule. However, the researcher always must be sure that the sample does not contain other molecules, which, alongside with the target one, inhibit aequorin bioluminescence.

\section{Photoprotein Pholasin and Its Analytical Application}

Photoprotein pholasin is isolated from the luminous seawater mollusk Pholas dactylus. In 2000, apo-pholasin (34.6 kDa) was cloned and expressed in E. coli cells [97], although the main source of this photoprotein is the cultivation of P. dactylus in the farm of Knight Scientific Ltd. (Plymouth, UK) (see its application example, [98]). The luminescence reaction of pholasin is triggered by reactive oxygen species such as superoxide anion and hydroxyl free radical so it is now widely used as an indicator of the superoxide anion radical (SAR) and other reactive oxygen species (ROS) in various fields of research. 
One of the recent pholasin applications is the quantification of leucocyte ROS production in response to various stimuli. Bryan and colleagues used the pholasin-based ROS assay to assess leukocyte respiratory burst response to biomaterials. They identified the role of a number of fabrication variables involved in the generation of tissue-based biomaterials in the down-stream leukocyte activation. A high degrees of leukocyte activation leads to poor material/patient compliance, accelerated degeneration, and graft rejection. The developed technique may be the way to guide host-material integration directed by the associated native tissue response to neutrophil ROS release and has the potential to be used as a routine component of presurgical evaluation to maximize foreign body compliance [99].

The same authors used pholasin to estimate the leukocyte ROS response for revealing differences in host reaction to several synthetic materials used in hernia repair [100]. Additionally, they utilized pholasin-based analysis to quantify leucocyte ROS production depending on the condition of the stem cell selection process [101].

Another pholasin application relates to studying the oxidative stress and inflammation during the disease course. Shah et al. used pholasin to evaluate superoxide anion $\left(\mathrm{O}_{2}{ }^{-}\right)$production in platelets of patients with heart failure [102]. Farthing et al. developed rapid and simple pholasin-based assay of inosine and hypoxanthine in human plasma, as potential biomarkers of acute cardiac ischemia [103]. The method has demonstrated the ability to distinguish between the healthy individuals, cases of non-traumatic chest pain, or potential acute cardiac ischemia. In study [104], the authors used pholasin for the measurement of whole blood antioxidant capacity at inflammatory processes, in particular in patients with rheumatoid arthritis and Parkinson's disease. They found that the approach provides the information clarifying the role of oxidative stress in the development of the diseases.

\section{CTZ-Dependent Luciferase Analytical Application}

As noted above, CTZ-dependent luciferases catalyze oxidation of the substrate yielding its decarboxylated derivative (CTM) and a quantum of blue light. They are relatively small proteins with molecular masses ranging from 36 (luciferase from coelenterate Renilla (RLuc) [105]) to $16.5 \mathrm{kDa}$ (one of the luciferase isoforms from copepod Metridia longa [106]). Luciferases, as opposed to $\mathrm{Ca}^{2+}$-regulated photoproteins, are not stable under chemical modifications and during the synthesis of biospecific conjugates can lose up to $60 \%$ of the initial bioluminescent activity (e.g., [107]). To overcome the problem, several original approaches were developed. So, the bioorthogonal conjugation or photoconjugation methods of obtaining luciferase-antibody conjugates that would provide a high conjugate yield, control over conjugation site and stoichiometry, and retention of the luciferase activity were elaborated $[108,109]$. However, the analytical application of luciferases in most cases is based on the bioluminescence of their derivatives extended with biospecific polypeptides obtained by genetic fusing. The Renilla luciferases, as the earliest studied ones, have been actively used as reporters, especially since 2006, when a variant RLuc8 with a significantly increased stability and bioluminescence yield was obtained using mutagenesis [110].

As a sensory component of hybrids, various biospecific polypeptides were applied-antibodies or their fragments [111-114], antigens [115-118], polypeptides with special binding ability [119-122], GFP and its color variants [123-129], etc. Based on the phenomenon of assembling split luciferase derivatives, a whole spectrum of homogeneous methods has been developed [125-129] and applied for studying protein-protein/ligand interaction [130-133], protein activity [134,135], and protein folding $[136,137]$.

The bioluminescence resonance energy transfer (BRET) assay (Figure 5) involving the use of RLuc has become popular since the late 1990s for measurements of protein-protein interactions and conformational rearrangements in live cells [138-140], for non-invasive bioimaging [141], and as probes for biosensing $[123,142]$. The sensitivity of BRET assays has recently been improved by introducing new BRET components: RLuc2 and RLuc8 with improved quantum yields, stability, and brightness [143] as well as a great variety of acceptors (GFP2, YFP, Venus, mOrange, TagRFP, TurboFP, semiconductor quantum dots or carbon-dots) [144-146]. However, the main application 
of RLuc is luciferase genetic reporter assay that has become an invaluable and routine tool for molecular biology research, including identification and characterization of protein functional variants [147,148], investigations of gene expression [148-150], transcription factors [151-155], receptor activity [156], miRNA expression [157-159], monitoring mRNA splicing events in cells $[160,161]$, virus investigations [162-164], drug discovery [165,166], and identification and evaluation of virus inhibitors $[167,168]$. Moreover, RLuc is widely used for bioluminescence imaging of different processes in vivo [169-171] and guiding drug delivery to cells [172,173].

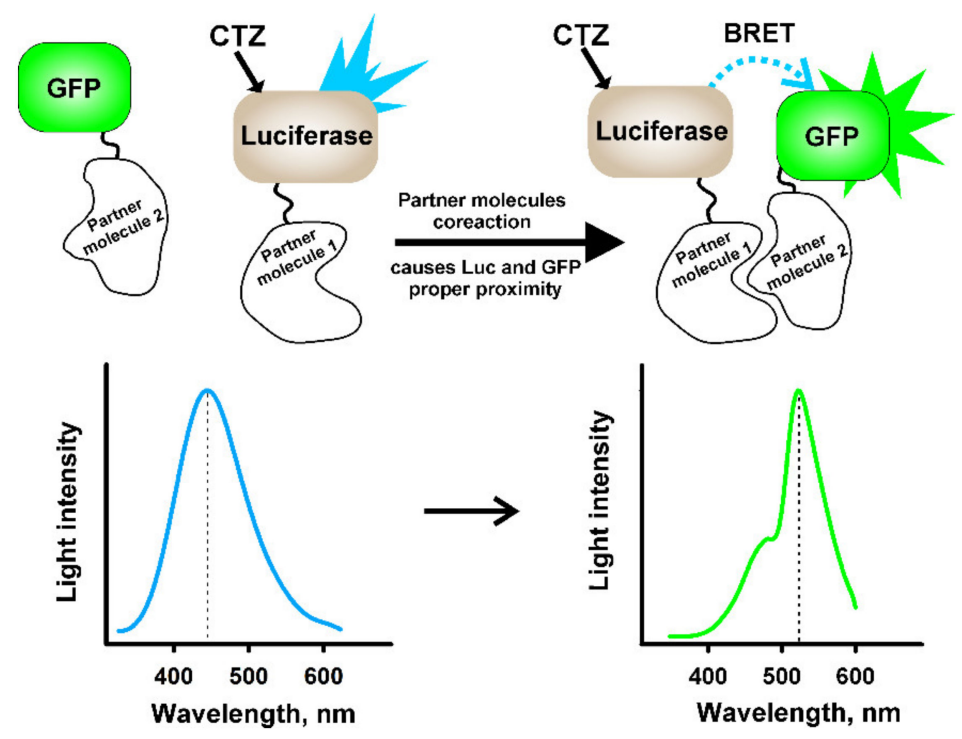

Figure 5. General principle of the BRET-based analytical systems.

The luciferases of marine copepods Metridia and Gaussia, although their properties are still poorly studied, are attracting attention as promising reporters because of their small size, unique thermal stability, and genetically encoded secretion system. This makes them ideal reporters for in vivo applications by providing capability of monitoring cellular events via measuring bioluminescence in culture media without cell lysis (see recent comprehensive review, [174]).

Of special interest is the artificial luciferase developed recently and named anoLuc due to its small size of $19 \mathrm{kDa}$. It derived from the luciferase of deep-sea shrimp Oplophorus gracilirostris. Native luciferase consists of two heterodimeric polypeptides: a small subunit of $19 \mathrm{kDa}$ (OLuc-19), which is responsible for bioluminescence activity but unstable in the absence of the $35 \mathrm{kDa}$ subunit. Structural optimization of the OLuc-19 after 3-round random mutagenesis yielded a stable enzyme with 16 amino acids replacement. It produces glow-type luminescence with a specific activity almost 81,000-fold greater than that of the initial OLuc-19, and 5-fold of that of RLuc (under the same reaction condition) [17]. A new developed coelenterazine variant, reported in the same paper-furimazine (Figure 2) - enhances the bioluminescence level by almost 25 times compared to coelenterazine and provides long-term signal $\left(\mathrm{t}_{1 / 2}=2.5 \mathrm{~h}\right)$ with a spectrum maximum at $460 \mathrm{~nm}$. The commercial availability of NanoLuc, its cleaved variants capable of assembling with the restoration of bioluminescence, and furimazine have promoted a wide range of their applications as a versatile and flexible analytical tool. The review by England and coworkers of 2016 (only 4 years after the first publication on NanoLuc) highlighted five main areas of successful use of the system, namely, the study of protein-protein and protein-ligand interactions, the study of gene regulation and cell signaling, protein stability monitoring, and use as BRET-based biosensors and bioluminescence imaging [175]. The system has been becoming increasingly popular, and here, we focus on some recent publications describing fundamentally new research. In general, analytical systems based on NanoLuc reporters are used in the same research areas as RLuc ones, but they successfully compete with them due to the significantly lower molecular weight and commercial availability of various variants of this enzyme 
provided by Promega Co along with manuals. The prefix Nano is often added to the names of such systems (NanoBRET, NanoBiT, etc.).

\subsection{NanoBit-Based Technologies}

The NanoBiT approach is based on splitting NanoLuc into two separate subunits-large BiT (LgBiT, $18 \mathrm{kDa}$ ) and small BiT (SmBiT, $1.3 \mathrm{kDa})$. These subunits interact very weakly $\left(\mathrm{K}_{\mathrm{D}}=190 \mu \mathrm{M}\right)$, so their assembly to form an active luminescent complex occurs only upon interaction of the separate binding partner proteins to which they are fused. In addition, the NanoBiT system includes subunit 11-amino-acid, HiBiT, with the essentially higher affinity to $\operatorname{LgBiT}\left(\mathrm{K}_{\mathrm{D}}=700 \mathrm{pM}\right)$. The protein of interest is genetically fused with HiBiT, and its expression is monitored by bioluminescence upon complementation with LgBiT in the presence of furimazine. So, while the SmBiT and LgBiT pair is applicable for detecting protein-protein interactions, the HiBiT acts as a detection tag for LgBiT.

The system is successfully applied for protein-protein and protein-ligand (receptor) interaction research, extremely important in molecular biology (Figure 6). The most traditional version of the analysis is based on the use of radioactive tracers, which is technologically difficult and dangerous. In the paper of Soave et al., camelid single-domain antibody fragment (nanobody) VUN400, which recognizes the second extracellular loop of the human CXCR4 chemokine receptor, was used as a probe to monitor specific CXCR4 conformations. VUN400 was fused with HiBiT tag (VUN400-HiBiT) which complements LgBiT protein, forming a functional NanoLuc luciferase. Complemented luminescence was used to detect VUN400-HiBiT binding to CXCR4 receptors expressed in living HEK293 cells. [176]. A similar approach used the NanoBiT complementation for a high-throughput method to monitor the loss of adenosine A1 receptor (A1ARs) from the cell surface in living cells. In this study, the A1ARs was tagged on the N-terminus with HiBiT tag [177].

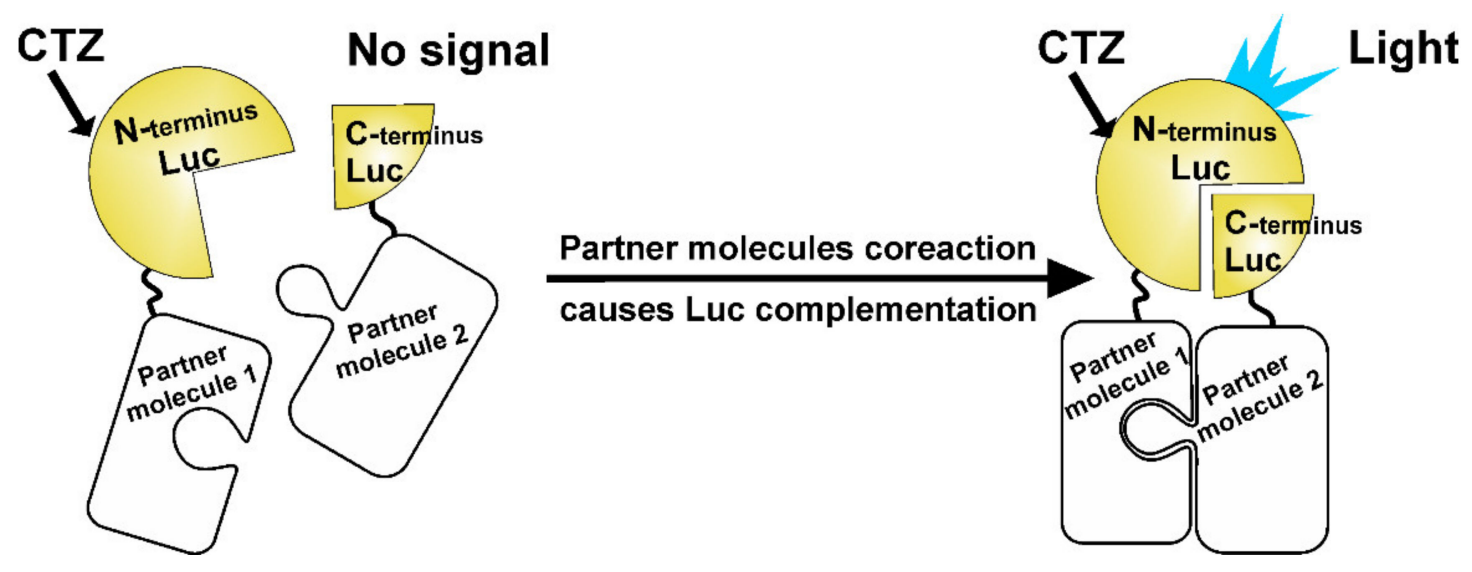

Figure 6. General principle of the assay based on the split luciferase complementation effect.

The NanoBiT system was applied to detect both strong and weak protein interactions such as those involving the binding of RAS oncoproteins to either RAF or phosphoinositide 3-kinase (PI3K) effectors, respectively, and was also shown to be effective for studying poorly soluble protein domains such as the RAS-binding domain of PI3K. [178].

Ubiquitination is a reversible post-translational modification of a protein that regulates many cellular processes (transcriptional signaling, protein degradation, protein transfer, and oncogenesis). To evaluate the ubiquitination processes, Boulch et al. fused SmBiT to ubiquitin and LgBiT to several ubiquitination substrates. The connection of ubiquitin to the substrate proteins of interest leads to reconstitution of NanoBiT reporter, and the corresponding luminescence signals are recorded with a microtiter plate reader. This approach is applicable to study ubiquitination in tissue culture systems or genetically amenable model organisms [179]. 
The Hippo signaling pathway regulates a variety of biological functions, and its dysregulation triggers the development of different cancer types. The Hippo pathway negatively regulates the activity of the transcriptional coactivators YAP and TAZ. TEAD is the main transcription factor that mediates YAP/TAZ oncogenic functions. It has been proposed that the disruption of the YAP/TAZ-TEAD interaction would be a way to restrain the transcriptional outputs of YAP/TAZ for cancer treatment. Using a NanoBiT system, a number of fuses containing NanoLuc fragments and YAP/TAZ or TEAD in different consequences were obtained and expressed in HEK293T cells. The combination of SmBiT-YAP/TAZ and LgBiT-TEAD demonstrated the highest sensitivity and dynamic range of analysis. The obtained YAP-TEAD and TAZ-TEAD biosensors were then successfully used in high-throughput small molecule drug screening [180].

The application of NanoBiT technology in binding assay in vitro is described in Section 4.3.

\subsection{NanoBRET-Based Technologies}

NanoLuc as the energy donor in BRET assay, termed nanoBRET [181], offers great application potential due to its obvious advantages over other BRET luciferases. First of all, the high quantum yield of NanoLuc and the possibility to combine BRET assay with NanoLuc-derived split luciferase reporter system (NanoBiT, described above) ensures the development of BRET assay with increased sensitivity. It allows the monitoring of protein-protein interactions at lower and more physiologically-relevant levels [182] and analysis of interactions with low selectivity or affinity which have previously been challenging [183,184]. The NanoLuc bioluminescence spectrum $\left(\lambda_{\max }=\sim 460 \mathrm{~nm}\right)$ is about $20 \%$ narrower compared with that of RLuc, enabling improved spectral separation of donor and acceptor emissions and the use of various fluorophores as acceptors. The numerous studies have demonstrated nanoBRET to utilize a broad range of fluorophores-from different fluorescent proteins (CyOFP, red-shifted CyOFP1, mNeonGreen, mScarlet, mCitrine, TurboFP635, mOrange, TagRFP, etc.) [185-190] to fluorescent dyes (TAMRA, BODIPY, 4-nitro-7-aminobenzofurazan (NBD), Alexa Fluor ${ }^{\mathrm{TM}}$, etc.) [191-195]. This greatly expands characteristics of the nanoBRET spectrum and also makes the development of microscopic nanoBRET imaging possible [195]. Fluorescent dyes in this case are conjugated to HaloTag protein (HaloTag system, see [196]). Small size of NanoLuc and its capacity to fold appropriately in extracellular environments has provided reason for its use in receptor-ligand binding studies where NanoLuc is fused to the extracellular N-terminus of the receptor without impairing localization at the plasma membrane [197]. Moreover, when used as a fusion reporter, NanoLuc is theoretically less likely to cause function-altering steric hindrance. This allows it to be used in BRET assays where the possibility of changing the function of a fusion structure can be a concern [198]. Comprehensive reviews on NanoBRET methodology and applications have been published recently [197,198]. NanoBRET is successfully used for studying protein-protein interactions [184,199], or investigations on receptor activation [190,199,200], oligomerization [201], conformational states [186], proximities [189,202], and receptor-ligand interactions [200,201,203]. NanoBRET technology has been also applied for in vivo imaging. For example, Min and colleagues generated a ratiometric BRET sensor of ATP for in vivo imaging of metabolic status [188]. Ong et al. developed a pH-sensitive nanoBRET sensor and demonstrated its diagnostic value for $\mathrm{pH}$ variations across the tumor microenvironment [204]. Taylor et al. showed NanoBRET in combination with firefly luciferase to unambiguously discriminate two cell populations in vivo with high sensitivity in the same imaging session [205]. To obtain red spectral emission, optimal for in vivo imaging with applicable BRET efficiency, appropriate acceptors were selected [195,206] and various synthetic coelenterazine analogues were utilized [207-209]. Additionally, based on nanoBRET technology, some genetically encoded calcium ion indicators were developed $[210,211]$ and used for imaging $\mathrm{Ca}^{2+}$ concentration changes in cultured cells and neurons [211].

Due to the remarkable increase in bioluminescence activity offered by NanoLuc, combined with its high thermal stability and $\mathrm{pH}$-insensitivity, NanoLuc-based BRET sensors have started to emerge as an attractive sensor format for use in point-of-care applications. Recently, nanoBRET sensor 
platforms for detection of small-molecule drugs (LUCiferase-based Indicators of Drugs, LUCIDs) and antibodies (LUMinescent AntiBody Sensor, LUMABS) have been developed by the groups led by M. Merkx. Sensing mechanisms of LUCIDs and LUMABS sensors are described in detail in [212,213]. These sensors allow measurement of antibodies directly in blood plasma, eliminating the need for the complex liquid handling steps associated with conventional immunoassays [214]. Bioluminescence can be easily registered with a smartphone digital camera [215]. The developed sensors were applied to detect anti-HIV1, anti-hemagglutinin, and anti-dengue virus type I antibodies $[212,214,215]$ as well as methotrexate, dinitrophenol, creatinine, and theophylline molecules $[212,213,216]$. In principal, the sensor's modular design allows the easy adaptation to many other analytes. Engelen W. et al. developed a NanoBRET-based protein-DNA hybrid molecular beacons sensor that permits the detection of low pM concentrations of nucleic acids (exemplified by miRNA21) directly in complex media. Due to the use of bright NanoLuc, these BRET beacons are at least 2 orders of magnitude more sensitive than the previously reported nucleic acid BRET sensors [217]. Moreover, nanoBRET-based homogeneous insulin assay was developed by Shigeto and colleagues [218]. The BRET signal was proportional to the insulin concentration, and the lower detection limit was $0.8 \mu \mathrm{M}$. An important step towards the application of LUCID, LUMABS, and other BRET-based diagnostic assays is the translation from a laboratory-based assay to a fully implemented point-of-care assay. The assay reported by Shigeto can be also applied to continuous monitoring of the time-dependent cellular response in vitro and as authors expected to drug development by high-throughput screening [218].

\subsection{Application of NanoLuc as a Label for In Vitro Binding Assay}

Similar to the other luciferases, NanoLuc loses its bioluminescent activity upon chemical conjugation with biospecific molecules: we could not find any published work regarding the preparation of such conjugates. Therefore, NanoLuc tags for in vitro binding assay are typically produced by genetic fusion with biospecific polypeptides-antibodies or antigenes. For example, Ren et al. genetically fused NanoLuc with aflatoxin-specific nanobody, obtained from an immune alpaca phage-display VHH library. The fusion protein was applied as a label in one-step competitive bioluminescent immunoassay for the detection of aflatoxin in cereal, which showed more than a 20-fold improvement in sensitivity as compared to classical ELISA [219]. NanoLuc fused with HIV-1 p24 or gp41 antigen was applied for qualitative and quantitative detection of anti-HIV-1 antibody in sera with the sensitivity exceeding that of ELISA 104-fold [220]. A similar assay was used to detect human norovirus-specific antibodies [221] or autoantibodies directed against proinsulin/insulin, which is important for diagnosis of type 1 diabetes [222].

Genetic fusion has the advantage of generating homogeneous conjugates with a well-defined antibody-luciferase stoichiometry. However, it requires cloning for each new antibody-luciferase conjugate and often involves cumbersome expression optimization and access to mammalian expression systems. Wouters et al. reported an easily accessible, efficient, and chemoselective method for the synthesis of antibody-luciferase conjugates. [109]. The NanoLuc was genetically fused with protein $\mathrm{G}$ domain containing the photo-cross-linkable non-natural amino acid para-benzoylphenylalanine (developed by Hui et al. [223]) that can be photo-cross-linked to the antibody using UV light illumination $(365 \mathrm{~nm})$. The method does not require cloning or recombinant antibody expression and can be directly applied to almost all human and many mammalian monoclonal IgG antibodies. The obtained NanoLuc-antibody conjugates were used in cell immunostaining, solid-phase immunoassay, and Western blotting [109].

The excellent thermostability of NanoLuc allows the obtaining of protein-based nanoparticles displaying multivalent NanoLuc on their surfaces. NanoLuc was genetically fused with elastin-like polypeptides containing poly-aspartic acid tail (ELP-D). Above the transition temperature $\left(40^{\circ} \mathrm{C}\right)$, the ELP-D forms aggregates whose sizes are regulated to around $30 \mathrm{~nm}$ as a result of the charge repulsion of the poly-aspartic acid chains. These particles displaying multiple molecules of NanoLuc were used as a detection probe in immunoassay of $\alpha$-fetoprotein. The sensitivity of the developed 
assay was 10 times higher than that of an assay relying on the use of the monomeric version of the fusion protein [224].

The original approach to obtain NanoLuc conjugate with DNA fragments was described in [225]. Luciferase was genetically fused with the catalytic domain of replication initiator protein (pRep) from porcine circovirus type 2. The trombin DNA aptamer elongated with the pRep recognition oligonucleotide was synthesized chemically. Stable non-covalent complex DNA-NanoLuc was obtained by mixing these two compounds and examining as a label in model trombin sandwich solid-phase assay, showing the excellent detection limit of $0.1 \mathrm{nM}$. The value of this method is that, in principle, it can be applied for the synthesis of many other DNA-luciferase complexes.

The T7 coliphage was genetically engineered to express the NanoLuc, and was used as a bioluminescent indicator of bacterial contamination [226]. In this construct, NanoLuc was fused to the carbohydrate binding module (CBM), providing specific binding of the reporter to crystalline cellulose. The engineered phage infected E. coli in the water sample (if any), resulting in NanoLuc-CBM expression. It was irreversibly immobilized on cellulose particles, which were added into the sample, and collected by centrifugation or fixed on a cellulose membrane by filtration. The reporter bioluminescence was measured on the addition of a substrate. The phage-based assay demonstrates its significant diagnostic value for inexpensive, rapid, and sensitive detection of E. coli in drinking water [226]. Due to the inherent specificity of phages for the respective bacteria, an approach can be developed to detect other bacterial contaminants. A similar approach was used to determine bacterial contamination in cheese [227].

Of special interest is the application of NanoBiT technology for in vitro binding assay. Even though bioluminescent reporters based on the luciferases of firefly, click beetle, or Renilla were split and extensively used as excellent reporters that display sensitive and reversible signals, these luciferases are not very stable and their reconstitution efficiency is not very high—-typically less than $1 \%$-as assumed by an in vitro experiment using purified probes (e.g., [228]). For this reason, the application of luciferase protein fragment complementation assay to in vitro diagnostics has been hampered in spite of its potentially wide applications as a sensitive homogeneous assay. Ohmuro-Matsuyama and Ueda have developed a homogeneous non-competitive open sandwich bioluminescent immunoassay of osteocalcin peptide using NanoLuc-based protein fragment complementation assays [229]. They additionally split LgBiT into two parts, yielding a smaller N-terminal derivative (LnBiT) and two C-terminal, 11-residue peptides (LcBiT and $\mathrm{SmBiT}$ ) corresponding to consecutive beta strands. These fragments were fused with variable regions $\mathrm{V}_{\mathrm{H}}$ and $\mathrm{V}_{\mathrm{L}}$ of anti-osteocalcin antibody, correspondingly. When LnBiT, $\mathrm{V}_{\mathrm{H}}$-LcBiT, and $\mathrm{V}_{\mathrm{L}}$-SmBiT were mixed, the bioluminescence intensity increased remarkably depending on the dose of osteocalcin peptide. The EC50 value and the detection limit were $123 \pm 16 \mathrm{nM}$ and $5 \mathrm{nM}$, respectively. Since the bioluminescent signal was strong and stable enough and could be observed with the naked eye or digital camera, it could become the foundation for developing many other point-of-care detection systems.

Ranawakage et al. used a NanoLuc-based HiBiT system to develop quantitative immunoprecipitation assay for determining the dissociation constant $(\mathrm{Kd})$ of antigen-antibody interactions in solution [230]. The assay applicability was demonstrated by examining the affinities of monoclonal antibodies against the epitope tags (FLAG, HA, V5, PA, and Ty1).

Tetsuo and colleagues developed a novel high-throughput serum neutralization test (SNT) for the serological diagnosis of infections (classical swine fever, bovine diarrhea, and borderline disease viruses) based on genetically engineered pestiviruses expressing the HiBiT peptide [231]. Swine or bovine kidney cells line were infected with recombinant viruses in serially diluted antiserum. Recombinant virus growth in cell culture occurs if the serum does not contain neutralizing antibodies. The luciferase activity of culture supernatants or cell lysates was measured using a Nano-Glo HiBiT lytic detection system (Promega, Madison, WI, USA). It depended on serum dilution and the time of virus inoculation. The authors concluded that the luciferase-based SNT will replace conventional SNTs. The proposed method is suitable for high-throughput testing for the control and study of pestiviruses. 


\subsection{NanoLuc in Genetic Reporter Assay}

NanoLuc application in luciferase genetic reporter assay does not fundamentally differ from the RLuc one. What is essentially new here is that due to the small size and extreme brightness of NanoLuc, it is widely used as an effective reporter in developing stable reporter viruses. These luciferase-tagged viruses are applicable not only for studying the virus life cycle in vitro and in vivo (viral proliferation, replication, assembly/release and entry) and analyzing virus-host interactions but also for evaluating therapeutic strategies and developing new inhibitors and vaccines. NanoLuc-based reporter viruses were successfully designed to study such dangerous diseases as: influenza A virus [232-236], hepatitis B [236-239] and E viruses [240], HIV [241], rotavirus [242], flavivirus [243-245], and arboviruses [246] which indicates the great potential of NanoLuc for such application.

In the recent years, CRISPR/Cas9 has emerged as a prominent technology for genome editing due to simplicity and ease of use. There are some publications describing the integration of NanoLuc gene directly into the endogenous gene using the CRISPR/Cas9 system. This allows efficient measurement of transcriptional activity for genes of interest in native epigenetic landscape which is not achievable under exogenous transfection-based luciferase reporter assays. The novel approach may provide new insights into understanding precise gene regulation in various developmental and pathophysiological conditions $[247,248]$. Moreover, the NanoLuc-based CRISPR/Cas9 system is a very useful tool to isolate gene-edited cells [248-250]. By combining the HiBiT reporter technology with the CRISPR/Cas9 editing, Schwinn et al. [251] developed the approach for sensitive quantification of both protein abundance and its post-translational modifications.

\section{Conclusions}

The analysis of the literature data on the use of coelenterazine-dependent luciferases as bioluminescent reporters clearly shows them to be a powerful analytical tool capable of solving a wide range of research and application problems. Figure 7 lists the main principles of analytical methods and the investigations that can be carried out on their basis. Some approaches are implemented involving both luciferases and $\mathrm{Ca}^{2+}$-regulated photoproteins, whereas some of them can be applied considering the unique capabilities of the reporters belonging only to each of these two groups. A number of approaches have become common and widely used, while others hold much promise for development analytics urgently needed for the present moment. A case in point here is the NanoLuc-based analytical system that Promega (USA) challenged to propose for the rapid detection of antibodies to SARS-Cov2 virus [252].

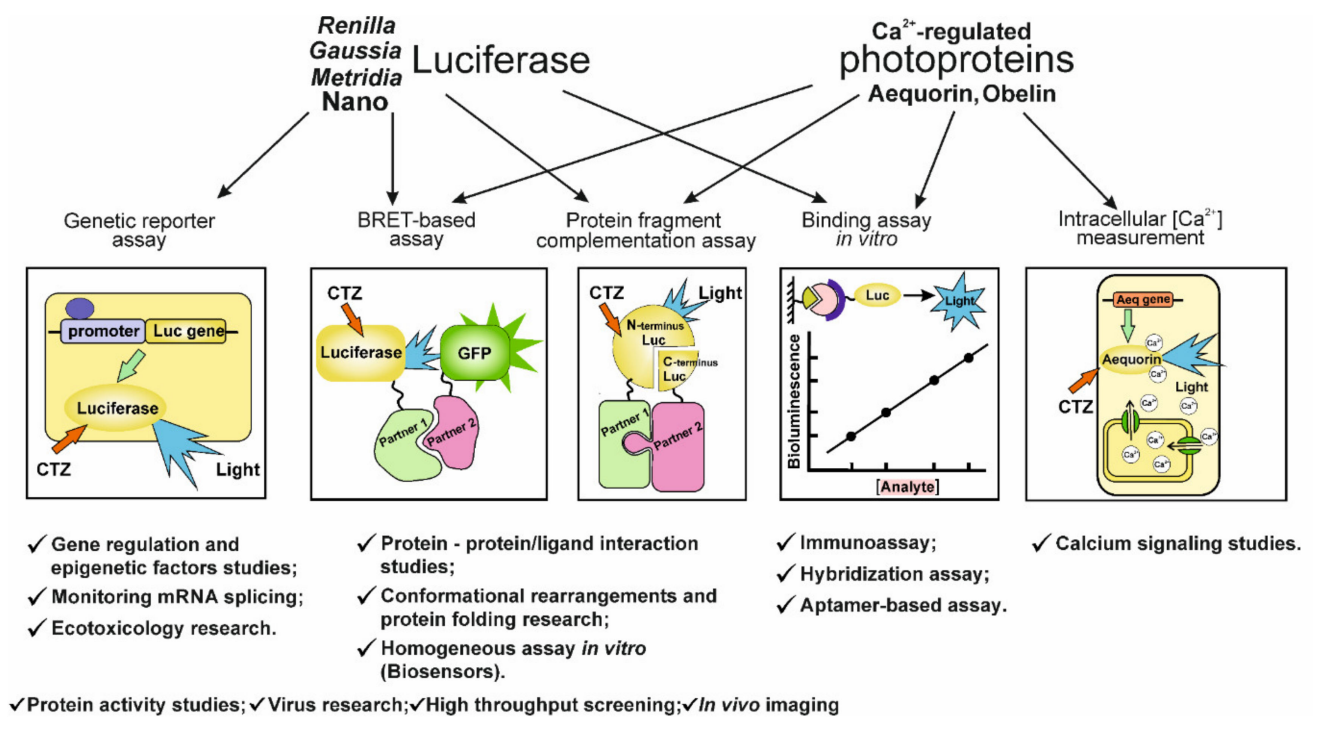

Figure 7. Main principles on the basis of which analytical methods and investigations can be carried out. 
A huge number of various enzymes and their substrates, including those artificially created and commercially available, which have various useful properties, provide a real opportunity for the experimenter to choose the option that best suits his needs. Within the framework of this review, we did not mention the availability of modern photometers-their variety and high analytical characteristics are able to satisfy the highest requirements of the users. Analytical approaches and methods based on these bioluminescent systems make it possible to successfully solve not only purely fundamental problems of modern biology. Their widespread introduction into practice of biomedical and environmental laboratories is also evident.

Author Contributions: Conceptualization, V.V.K., E.E.B., and L.A.F.; analysis of literature data, writing and revision of the manuscript, V.V.K., E.E.B., and L.A.F.; illustrations design and preparation, V.V.K. and E.E.B.; funding acquisition, L.A.F. All authors have read and agreed to the published version of the manuscript.

Funding: The work was supported by the Russian State funded budget project of IBP SB RAS No. AAAA-A19-119031890015-0.

Acknowledgments: The authors are grateful to N.P. Malikova (Institute of Biophysics SB RAS) for the kindly provided material presented in Figure 3.

Conflicts of Interest: The authors declare no conflict of interest. The funder had no role in the study design; collection, analysis, and interpretation of the data; or the decision to prepare or to publish the manuscript.

$\begin{array}{ll}\text { Abbreviations } \\ \text { CTZ } & \text { coelenterazine } \\ \text { CTM } & \text { coelenteramide, decarboxylated derivative of CTZ } \\ \text { Luc } & \text { luciferase } \\ \text { PhP } & \mathrm{Ca}^{2+} \text {-regulated photoprotein } \\ \text { apoPhP } & \text { polypeptide part of PhP } \\ \text { CBP } & \mathrm{Ca}^{2+} \text {-dependent coelenterazine-binding protein } \\ \text { apoCBP } & \text { polypeptide part of CBP } \\ \text { GFP } & \text { green fluorescent protein } \\ \text { EF-hand } & \text { The Ca }{ }^{2+} \text {-binding sites formed by helix-loop-helix } \\ & \text { motifs }\end{array}$

\section{References}

1. Shimomura, O.; Yampolsky, I. Bioluminescence: Chemical Principles and Methods, 3rd ed.; World Scientific Publishing: Singapore, 2019. [CrossRef]

2. Markova, S.V.; Vysotski, E.S. Coelenterazine-dependent luciferases. Biochemistry 2015, 80, 714-732. [CrossRef] [PubMed]

3. Frank, L.A. Creation of artificial luciferases to expand their analytical potential. Comb. Chem. High. Throughput Screen. 2015, 18, 919-929. [CrossRef]

4. Eremeeva, E.V.; Vysotski, E.S. Exploring bioluminescence function of the $\mathrm{Ca}^{2+}$-regulated photoproteins with site-directed mutagenesis. Photochem. Photobiol. 2019, 95, 8-23. [CrossRef] [PubMed]

5. Stepanyuk, G.A.; Liu, Z.J.; Markova, S.S.; Frank, L.A.; Lee, J.; Vysotski, E.S.; Wang, B.C. Crystal structure of coelenterazine-binding protein from Renilla muelleri at $1.7 \mathrm{~A}$ : Why it is not a calcium-regulated photoprotein. Photochem. Photobiol. Sci. 2008, 7, 442-447. [CrossRef] [PubMed]

6. Stepanyuk, G.A.; Liu, Z.J.; Vysotski, E.S.; Lee, J.; Rose, J.P.; Wang, B.C. Structure based mechanism of the $\mathrm{Ca}(2+)$-induced release of coelenterazine from the Renilla binding protein. Proteins Struct. Funct. Bioinform. 2009, 74, 583-593. [CrossRef] [PubMed]

7. Titushin, M.S.; Markova, S.V.; Frank, L.A.; Malikova, N.P.; Stepanyuk, G.A.; Lee, J.; Vysotski, E.S. Coelenterazine-binding protein of Renilla muelleri: cDNA cloning, overexpression, and characterization as a substrate of luciferase. Photochem. Photobiol. Sci. 2008, 7, 189-196. [CrossRef] [PubMed]

8. Shimomura, O. Membrane permeability of coelenterazine analogues measured with fish eggs. Biochem. J. 1997, 326, 297-298. [CrossRef] [PubMed] 
9. Stepanyuk, G.A.; Unch, J.; Malikova, N.P.; Markova, S.V.; Lee, J.; Vysotski, E.S. Coelenterazine-v ligated to $\mathrm{Ca}^{2+}$-triggered coelenterazine-binding protein is a stable and efficient substrate of the red-shifted mutant of Renilla muelleri luciferase. Anal. Bioanal. Chem. 2010, 398, 1809-1817. [CrossRef] [PubMed]

10. Krasitskaya, V.V.; Korneeva, S.I.; Kudryavtsev, A.N.; Markova, S.V.; Stepanyuk, G.A.; Frank, L.A. $\mathrm{Ca}^{2+}$-triggered coelenterazine-binding protein from Renilla as an enzyme-dependent label for binding assay. Anal. Bioanal. Chem. 2011, 401, 2573-2579. [CrossRef] [PubMed]

11. Kudryavtsev, A.N.; Burakova, L.P.; Frank, L.A. Bioluminescent detection of tick-borne encephalitis virus in native ticks. Anal. Methods 2017, 9, 2252-2255. [CrossRef]

12. Kuse, M. Chromophores in photoproteins of a glowing squid and mollusk. Biosci. Biotechnol. Biochem. 2014, 78, 731-736. [CrossRef] [PubMed]

13. Shimomura, O.; Johnson, F.H.; Saiga, Y. Extraction, purification and properties of aequorin, a bioluminescent protein from the luminous hydromedusan, Aequorea. J. Cell Comp. Physiol. 1962, 59, 223-239. [CrossRef] [PubMed]

14. Shimomura, O. Structure of the chromophore of Aequorea green fluorescent protein. FEBS Lett. 1979, 104, 220-222. [CrossRef]

15. Craggs, T.D. Green fluorescent protein: Structure, folding and chromophore maturation. Chem. Soc. Rev. 2009, 38, 2865-2875. [CrossRef]

16. Teranishi, K. Luminescence of imidazo[1,2-a]pyrazin-3(7H)-one compounds. Bioorganic Chem. 2007, 35, 82-111. [CrossRef]

17. Hall, M.P.; Unch, J.; Binkowski, B.F.; Valley, M.P.; Butler, B.L.; Wood, M.G.; Otto, P.; Zimmerman, K.; Vidugiris, G.; Machleidt, T.; et al. Engineered luciferase reporter from a deep sea shrimp utilizing a novel imidazopyrazinone substrate. ACS Chem. Biol. 2012, 7, 1848-1857. [CrossRef]

18. Giuliani, G.; Molinari, P.; Ferretti, G.; Cappelli, A.; Anzini, M.; Vomero, S.; Costa, T. New red-shifted coelenterazine analogues with an extended electronic conjugation. Tetrahedron Lett. 2012, 53, 5114-5118. [CrossRef]

19. Contant, E.P.; Goyard, S.; Hervin, V.; Gagnot, G.; Baatallah, R.; Jacob, Y.; Rose, T.; Janin, Y. Gram-scale synthesis of luciferins derived from coelenterazine and original insight into their bioluminescence properties. Org. Biomol. Chem. 2019, 17, 3709-3713. [CrossRef]

20. Contant, E.P.; Gagnot, G.; Hervin, V.; Baatallah, R.; Goyard, S.; Jacob, Y.; Rose, T.; Janin, Y.L. Bioluminescence profiling of NanoKAZ/NanoLuc luciferase using a chemical library of coelenterazine analogues. Chem. Eur. J. 2020, 26, 948-958. [CrossRef]

21. Head, J.F.; Inouye, S.; Teranishi, K.; Shimomura, O. The crystal structure of the photoprotein aequorin at $2.3 \AA$ resolution. Nature 2000, 405, 372-376. [CrossRef]

22. Liu, Z.J.; Vysotski, E.S.; Deng, L.; Lee, J.; Rose, J.P.; Wang, B.C. Atomic resolution structure of obelin: Soaking with calcium enhances electron density of the second oxygen atom substituted at the C2-position of coelenterazine. Biochem. Biophys. Res. Commun. 2003, 311, 433-439. [CrossRef] [PubMed]

23. Vysotski, E.S.; Lee, J. $\mathrm{Ca}^{2+}$-regulated photoproteins: Structural insight into the bioluminescence mechanism. Acc. Chem. Res. 2004, 37, 405-415. [CrossRef] [PubMed]

24. Grinstead, K.; Joel, S.; Zingg, J.M.; Dikici, E.; Daunert, S. Enabling aequorin for biotechnology applications through genetic engineering. Adv. Biochem. Eng. Biotechnol. 2015, 3, 149-179. [CrossRef]

25. Qu, X.; Rowe, L.; Dikici, E.; Ensor, M.; Daunert, S. Aequorin mutants with increased thermostability. Anal. Bioanal. Chem. 2014, 406, 5639-5643. [CrossRef]

26. Blinks, J.R. Use of photoproteins as intracellular calcium indicators. Environ. Health Perspect. 1990, 84, 75-81. [CrossRef] [PubMed]

27. Berridge, M.J.; Lipp, P.; Bootman, M.D. The versatility and universality of calcium signalling. Nat. Rev. Mol. Cell Biol. 2000, 1, 11-21. [CrossRef]

28. Mank, M.; Griesbeck, O. Genetically encoded calcium indicators. Chem. Rev. 2008, 108, 1550-1564. [CrossRef]

29. Ottolini, D.; Calì, T.; Brini, M. Measurements of $\mathrm{Ca}^{2+}$ concentration with recombinant targeted luminescent probes. Methods Mol. Biol. 2013, 937, 273-291. [CrossRef]

30. Bonora, M.; Giorgi, C.; Bononi, A.; Marchi, S.; Patergnani, S.; Rimessi, A.; Rizzuto, R.; Pinton, P. Subcellular calcium measurements in mammalian cells using jellyfish photoprotein aequorin-based probes. Nat. Protoc. 2013, 8, 2105-2118. [CrossRef]

31. Malikova, N.P.; Burakova, L.P.; Markova, S.V.; Vysotski, E.S. Characterization of hydromedusan $\mathrm{Ca}^{2+}$-regulated photoproteins as a tool for measurement of $\mathrm{Ca}^{2+}$ concentration. Anal. Bioanal. Chem. 2014, 406, 5715-5726. [CrossRef] 
32. Malikova, N.P.; Borgdorff, A.J.; Vysotski, E.S. Semisynthetic photoprotein reporters for tracking fast $\mathrm{Ca}^{2+}$ transients. Photochem. Photobiol. Sci. 2015, 14, 2213-2224. [CrossRef] [PubMed]

33. Markova, S.V.; Burakova, L.P.; Golz, S.; Malikova, N.P.; Frank, L.A.; Vysotski, E.S. The light-sensitive photoprotein berovin from the bioluminescent ctenophore Beroe abyssicola: A novel type of $\mathrm{Ca}^{2+}$-regulated photoprotein. FEBS J. 2012, 279, 856-870. [CrossRef] [PubMed]

34. Jafarian, V.; Sariri, R.; Hosseinkhani, S.; Aghamaali, M.R.; Sajedi, R.H.; Taghdir, M.; Hassannia, S. A unique EF-hand motif in mnemiopsin photoprotein from Mnemiopsis leidyi: Implication for its low calcium sensitivity. Biochem. Biophys. Res. Commun. 2011, 413, 164-170. [CrossRef] [PubMed]

35. De la Fuente, S.; Fonteriz, R.I.; de la Cruz, P.J.; Montero, M.; Alvarez, J. Mitochondrial free $\left[\mathrm{Ca}^{2+}\right]$ dynamics measured with a novel low-Ca ${ }^{2+}$ affinity aequorin probe. Biochem. J. 2012, 445, 371-376. [CrossRef] [PubMed]

36. De la Fuente, S.; Fonteriz, R.I.; Montero, M.; Alvarez, J. Ca ${ }^{2+}$ homeostasis in the endoplasmic reticulum measured with a new low-Ca ${ }^{2+}$-affinity targeted aequorin. Cell Calcium 2013, 54, 37-45. [CrossRef]

37. Grinstead, K.M.; Rowe, L.; Ensor, C.M.; Joel, S.; Daftarian, P.; Dikici, E.; Zingg, J.M.; Daunert, S. Red-shifted aequorin variants incorporating non-canonical amino acids: Applications in in vivo imaging. PLOS ONE 2016, 11, e0158579. [CrossRef]

38. Jalilian, N.; Shanehsaz, M.; Sajedi, R.H.; Gharaat, M.; Ghahremanzadeh, R. Improving the luminescence properties of aequorin by conjugating to CdSe/ZnS quantum dot nanoparticles: Red shift and slowing decay rate. J. Photochem. Photobiol. B 2016, 162, 153-161. [CrossRef]

39. Bakayan, A.; Domingo, B.; Vaquero, C.F.; Peyriéras, N.; Llopis, J. Fluorescent protein-photoprotein fusions and their applications in calcium imaging. Pflïgers Arch. 2015, 467, 2031-2042. [CrossRef]

40. Bakayan, A.; Domingo, B.; Miyawaki, A.; Llopis, J. Imaging Ca ${ }^{2+}$ activity in mammalian cells and zebrafish with a novel red-emitting aequorin variant. Pflügers Arch. 2015, 467, 2031-2042. [CrossRef]

41. Campbell, R.E.; Tour, O.; Palmer, A.E.; Steinbach, P.A.; Baird, G.S.; Zacharias, D.A.; Tsien, R.Y. A monomeric red fluorescent protein. Proc. Natl. Acad. Sci. USA 2002, 99, 7877-7882. [CrossRef]

42. Manjarres, I.M.; Chamero, P.; Domingo, B.; Molina, F.; Llopis, J.; Alonso, M.T.; Garcia-Sancho, J. Red and green aequorins for simultaneous monitoring of $\mathrm{Ca}^{2+}$ signals from two different organelles. Pflügers Arch. 2008, 455, 961-970. [CrossRef] [PubMed]

43. Vicente, M.; Salgado-Almario, J.; Soriano, J.; Burgos, M.; Domingo, B.; Llopis, J. Visualization of mitochondrial $\mathrm{Ca}^{2+}$ signals in skeletal muscle of zebrafish embryos with bioluminescent indicators. Int. J. Mol. Sci. 2019, 20, 5409. [CrossRef] [PubMed]

44. Drobac, E.; Tricoire, L.; Chaffotte, A.F.; Guiot, E.; Lambolez, B. Calcium imaging in single neurons from brain slices using bioluminescent reporters. J. Neurosci. Res. 2010, 88, 695-711. [CrossRef]

45. Cabrero, P.; Richmond, L.; Nitabach, M.; Davies, S.A.; Dow, J.A.T. A biogenic amine and a neuropeptide act identically: Tyramine signals through calcium in Drosophila tubule stellate cells. Proc. R. Soc. B Biol. Sci. 2013, 280, 2012-2943. [CrossRef]

46. Pavot, P.; Carbognin, E.; Martin, J.R. PKA and cAMP/CNG channels independently regulate the cholinergic $\mathrm{Ca}^{2+}$-response of Drosophila mushroom body neurons. eNeuro 2015, 2, e0054-14. [CrossRef]

47. Murmu, M.S.; Stinnakre, J.; Martin, J.R. Presynaptic $\mathrm{Ca}^{2+}$ stores contribute to odor-induced responses in Drosophila olfactory receptor neurons. J. Exp. Biol. 2010, 213, 4163-4173. [CrossRef] [PubMed]

48. Minocci, D.; Carbognin, E.; Murmu, M.S.; Martin, J.R. In vivo functional calcium imaging of induced or spontaneous activity in the fly brain using a GFP-apoaequorin-based bioluminescent approach. Biochim. Biophys. Acta. 2013, 1833, 1632-1640. [CrossRef]

49. Marescotti, M.; Lagogiannis, K.; Webb, B.; Davies, R.W.; Armstrong, J.D. Monitoring brain activity and behaviour in freely moving Drosophila larvae using bioluminescence. Sci. Rep. 2018, 8, 9246. [CrossRef]

50. Naumann, E.A.; Kampff, A.R.; Prober, D.A.; Schier, A.F.; Engert, F. Monitoring neural activity with bioluminescence during natural behavior. Nat. Neurosci. 2010, 13, 513-520. [CrossRef]

51. Cheung, C.Y.; Webb, S.E.; Love, D.R.; Miller, A.L. Visualization, characterization and modulation of calcium signaling during the development of slow muscle cells in intact zebrafish embryos. Int. J. Dev. Biol. 2011, 55, 153-174. [CrossRef]

52. Webb, S.E.; Cheung, C.C.Y.; Chan, C.M.; Love, D.R.; Miller, A.L. Application of complementary luminescent and fluorescent imaging techniques to visualize nuclear and cytoplasmic $\mathrm{Ca}^{2+}$ signalling during the in vivo differentiation of slow muscle cells in zebrafish embryos under normal and dystrophic conditions. Clin. Exp. Pharmacol. Physiol. 2012, 39, 78-86. [CrossRef] [PubMed] 
53. Kelu, J.J.; Chan, H.L.; Webb, S.E.; Cheng, A.H.; Ruas, M.; Parrington, J.; Galione, A.; Miller, A.L. Two-pore channel 2 activity is required for slow muscle cell-generated $\mathrm{Ca}^{2+}$ signaling during myogenesis in intact zebrafish. Int. J. Dev. Biol. 2015, 59, 313-325. [CrossRef] [PubMed]

54. Webb, S.E.; Miller, A.L. The use of complementary luminescent and fluorescent techniques for imaging $\mathrm{Ca}^{2+}$ signaling events during the early development of Zebrafish (Danio rerio). Methods Mol. Biol. 2019, 1929, 73-93. [CrossRef] [PubMed]

55. Qian, H.; Chen, Q.; Zhang, S.; Lu, L. The claudin family protein FigA mediates $\mathrm{Ca}^{2+}$ homeostasis in response to extracellular stimuli in Aspergillus nidulans and Aspergillus fumigatus. Front. Microbiol. 2018, 9, 977. [CrossRef]

56. Zhu, X.; Feng, Y.; Liang, G.; Liu, N.; Zhu, J.K. Aequorin-based luminescence imaging reveals stimulus- and tissue-specific $\mathrm{Ca}^{2+}$ dynamics in Arabidopsis plants. Mol. Plant. 2013, 6, 444-455. [CrossRef]

57. Tran, D.; Dauphin, A.; Meimoun, P.; Kadono, T.; Nguyen, H.T.H.; Arbelet-Bonnin, D.; Zhao, T.; Errakhi, R.; Lehner, A.; Kawano, T.; et al. Methanol induces cytosolic calcium variations, membrane depolarization and ethylene production in arabidopsis and tobacco. Ann. Bot. 2018, 122, 849-860. [CrossRef] [PubMed]

58. Yu, Z.; Taylor, J.L.; He, Y.; Ni, J. Enlightenment on the aequorin-based platform for screening Arabidopsis stress sensory channels related to calcium signaling. Plant. Signal. Behav. 2015, 10, e1057366. [CrossRef]

59. Sello, S.; Moscatiello, R.; Mehlmer, N.; Leonardelli, M.; Carraretto, L.; Cortese, E.; Zanella, F.G.; Baldan, B.; Szabò, I.; Vothknecht, U.C.; et al. Chloroplast $\mathrm{Ca}^{2+}$ fluxes into and across thylakoids revealed by thylakoid-targeted aequorin probes. Plant. Physiol. 2018, 177, 38-51. [CrossRef]

60. Moroz, N.; Tanaka, K. FlgII-28 is a major flagellin-derived defense elicitor in potato. Mol. Plant. Microbe Interact. 2020, 33, 247-255. [CrossRef]

61. Nguyena, H.T.H.; Bouteaub, F.; Mazarsd, C.; Kusee, M.; Kawano, T. Enhanced elevations of hypo-osmotic shock-induced cytosolic and nucleic calcium concentrations in tobacco cells by pretreatment with dimethyl sulfoxide. Biosci. Biotechnol. Biochem. 2019, 83, 318-321. [CrossRef]

62. Moscatiello, R.; Sello, S.; Ruocco, M.; Barbulova, A.; Cortese, E.; Nigris, S.; Baldan, B.; Chiurazzi, M.; Mariani, P.; Lorito, M.; et al. The hydrophobin HYTLO1 secreted by the biocontrol fungus trichoderma longibrachiatum triggers a NAADP-mediated calcium signalling pathway in Lotus japonicus. Int. J. Mol. Sci. 2018, 19, 2596. [CrossRef] [PubMed]

63. Ruta, L.L.; Nicolau, I.; Popa, C.V.; Farcasanu, I.C. Manganese suppresses the haploinsufficiency of heterozygous trpy1D/TRPY1 Saccharomyces cerevisiae cells and stimulates the TRPY1-dependent release of vacuolar $\mathrm{Ca}^{2+}$ under $\mathrm{H}_{2} \mathrm{O}_{2}$ Stress. Cells 2019, 8, 79. [CrossRef] [PubMed]

64. Brochet, M.; Collins, M.O.; Smith, T.K.; Thompson, E.; Sebastian, S.; Volkmann, K.; Schwach, F.; Chappell, L.; Gomes, A.R.; Berriman, M.; et al. Phosphoinositide metabolism links cGMP-dependent protein kinase G to essential $\mathrm{Ca}^{2+}$ signals at key decision points in the life cycle of Malaria parasites. PLoS Biol. 2014, 12, e100180. [CrossRef] [PubMed]

65. Frank, L.A. $\mathrm{Ca}^{2+}$-regulated photoproteins: Effective immunoassay reporters. Sensors 2010, 10, 11287-11300. [CrossRef]

66. Krasitskaya, V.V.; Frank, L.A. Application of enzyme bioluminescence for medical diagnostics. Adv. Biochem. Eng. Biotechnol. 2014, 144, 175-197. [CrossRef]

67. Daunert, S.; Deo, S.K. Photoproteins in Bioanalysis; Wiley-VCH Verlag GmbH \& Co. KGaA: Weinheim, Germany, 2006. [CrossRef]

68. Frank, L.A.; Borisova, V.V.; Markova, S.V.; Malikova, N.P.; Stepanyuk, G.A.; Vysotski, E.S. Violet and greenish photoprotein obelin mutants for reporter applications in dual-color assay. Anal. Bioanal. Chem. 2008, 391, 2891-2896. [CrossRef]

69. Krasitskaya, V.V.; Kudryavtsev, A.N.; Shimomura, O.; Frank, L.A. Obelin mutants as reporters in bioluminescent dual-analyte binding assay. Anal. Methods 2013, 5, 636-640. [CrossRef]

70. Kudryavtsev, A.N.; Krasitskaya, V.V.; Petunin, A.I.; Burakov, A.Y.; Frank, L.A. Simultaneous bioluminescent immunoassay of serum total and IgG-bound prolactins. Anal. Chem. 2012, 84, 3119-3124. [CrossRef]

71. Bashmakova, E.E.; Krasitskaya, V.V.; Frank, L.A. Simultaneous genotyping of four single nucleotide polymorphisms associated with risk factors of hemostasis disorders. Comb. Chem. High. Throughput Screen. 2015, 18, 930-936. [CrossRef]

72. Bashmakova, E.E.; Krasitskaya, V.V.; Bondar, A.A.; Kozlova, A.V.; Ruksha, T.G.; Frank, L.A. Bioluminescent assay to detect melanocortin-1 receptor (MC1R) polymorphisms (R160W, R151C, and D294H). Mol. Biol. 2015, 49, 852-857. [CrossRef] 
73. Bashmakova, E.E.; Krasitskaya, V.V.; Bondar, A.A.; Eremina, E.N.; Slepov, E.V.; Zukov, R.A.; Frank, L.A. Bioluminescent SNP genotyping technique: Development and application for detection of melanocortin 1 receptor gene polymorphisms. Talanta 2018, 189, 111-115. [CrossRef] [PubMed]

74. Yu, X.; Scott, D.; Dikici, E.; Joel, S.; Deo, S.; Daunert, S. Multiplexing cytokine analysis: Towards reducing sample volume needs in clinical diagnostics. Analyst 2019, 144, 3250-3259. [CrossRef] [PubMed]

75. Inouye, S.; Sato, J. Purification of histidine-tagged aequorin with a reactive cysteine residue for chemical conjugations and its application for bioluminescent sandwich immunoassays. Protein Expr. Purif. 2012, 83, 205-210. [CrossRef] [PubMed]

76. Krasitskaya, V.V.; Burakova, L.P.; Komarova, A.A.; Bashmakova, E.E.; Frank, L.A. Mutants of Ca ${ }^{2+}$-regulated photoprotein obelin for site-specific conjugation. Photochem. Photobiol. 2017, 93, 553-557. [CrossRef]

77. Sun, H.; Zu, Y. A highlight of recent advances in aptamer technology and its application. Molecules 2015, 20, 11959-11980. [CrossRef]

78. Bashmakova, E.E.; Krasitskaya, V.V.; Zamay, G.S.; Zamay, T.N.; Frank, L.A. Bioluminescent aptamer-based solid-phase microassay to detect lung tumor cells in plasma. Talanta 2019, 199, 674-678. [CrossRef]

79. Vorobjeva, M.A.; Krasitskaya, V.V.; Fokina, A.A.; Timoshenko, V.V.; Nevinsky, G.A.; Venyaminova, A.G.; Frank, L.A. RNA aptamer against autoantibodies associated with multiple sclerosis and bioluminescent detection probe on its basis. Anal. Chem. 2014, 86, 2590-2594. [CrossRef]

80. Krasitskaya, V.V.; Chaukina, V.V.; Abroskina, M.V.; Vorobyeva, M.A.; Ilminskaya, A.A.; Prokopenko, S.V.; Nevinsky, G.A.; Venyaminova, A.G.; Frank, L.A. Bioluminescent aptamer-based sandwich-type assay of anti-myelin basic protein autoantibodies associated with multiple sclerosis. Anal. Chim. Acta 2019, 1064, 112-118. [CrossRef]

81. Krasitskaya, V.V.; Goncharova, N.S.; Biriukov, V.V.; Bashmakova, E.E.; Kabilov, M.R.; Baykov, I.K.; Sokolov, A.E.; Frank, L.A. The $\mathrm{Ca}^{2+}$-regulated photoprotein obelin as a tool for SELEX monitoring and DNA aptamer affinity evaluation. Photochem. Photobiol. 2020, 96, 1041-1046. [CrossRef]

82. Davydova, A.; Vorobyeva, M.; Bashmakova, E.; Vorobjev, P.; Krasheninina, O.; Tupikin, A.; Kabilov, M.; Krasitskaya, V.; Frank, L.; Venyaminova, A. Development and characterization of novel 2'-F-RNA aptamers specific to human total and glycated hemoglobins. Anal. Biochem. 2019, 570, 43-50. [CrossRef]

83. Krasitskaya, V.V.; Davydova, A.S.; Vorobyeva, M.A.; Frank, L.A. The $\mathrm{Ca}^{2+}$-regulated photoprotein obelin as a target for the RNA aptamer selection. Russ. J. Bioorg. Chem. 2018, 44, 296-301. [CrossRef]

84. Davydova, A.S.; Krasitskaya, V.V.; Vorobjev, P.E.; Krasheninina, O.A.; Tupikin, A.E.; Kabilov, M.R.; Frank, L.A.; Venyaminova, A.G.; Vorobyeva, M.A. RNA aptamer to photoprotein obelin: A reporter-recruiting module for novel bioluminescent aptasensing systems. RSC Adv. 2020, 10, 32393-32399. [CrossRef]

85. Inouye, S.; Sato, J.; Sasaki, S.; Sahara, Y. Streptavidin-aequorin fusion protein for bioluminescent immunoassay. Biosci. Biotechnol. Biochem. 2011, 75, 568-571. [CrossRef] [PubMed]

86. Bashmakova, E.E.; Krasitskaya, V.V.; Kudryavtsev, A.N.; Grigorenko, V.G.; Frank, L.A. Hybrid minimal core streptavidin-obelin as a versatile reporter for bioluminescence-based bioassay. Photochem. Photobiol. 2017, 93, 548-552. [CrossRef] [PubMed]

87. Inouye, S.; Sahara-Miura, Y. A fusion protein of the synthetic IgG-binding domain and aequorin: Expression and purification from E. coli cells and its application. Protein Expr. Purif. 2017, 137, 58-63. [CrossRef] [PubMed]

88. Krasitskaya, V.V.; Bashmakova, E.E.; Kudryavtsev, A.N.; Vorobjeva, M.A.; Shatunova, E.A.; Frank, L.A. Hybrid protein ZZ-OL as an analytical tool for biotechnology research. Russ. J. Bioorg. Chem. 2020, 45. in press.

89. Markova, S.V.; Vysotski, E.S.; Blinks, J.R.; Burakova, L.P.; Wang, B.C.; Lee, J. Obelin from the bioluminescent marine hydroid Obelia geniculata: Cloning, expression, and comparison of some properties with those of other $\mathrm{Ca}^{2+}$-regulated photoproteins. Biochemistry 2002, 41, 2227-2236. [CrossRef]

90. Eremeeva, E.V.; Burakova, L.P.; Krasitskaya, V.V.; Kudryavtsev, A.N.; Shimomura, O.; Frank, L.A. Hydrogen-bond network between C-terminus and Arg from the first $\alpha$-helix stabilizes a photoprotein molecule. Photochem. Photobiol. Sci. 2014, 13, 541-547. [CrossRef]

91. Hamorsky, K.T.; Ensor, C.M.; Wei, Y.; Daunert, S. A bioluminescent molecular switch for glucose. Angew. Chem. Int. Ed. Engl. 2008, 47, 3718-3721. [CrossRef]

92. Scott, D.; Hamorsky, K.T.; Ensor, C.M.; Anderson, K.W.; Daunert, S. Cyclic AMP receptor protein-aequorin molecular switch for cyclic AMP. Bioconjugate Chem. 2011, 22, 475-481. [CrossRef] 
93. Hamorsky, K.T.; Ensor, C.M.; Pasini, P.; Daunert, S. A protein switch sensing system for the quantification of sulfate. Anal. Biochem. 2012, 421, 172-180. [CrossRef] [PubMed]

94. Hamorsky, K.T.; Ensor, C.M.; Dikici, E.; Pasini, P.; Bachas, L.; Daunert, S. Bioluminescence inhibition assay for the detection of hydroxylated polychlorinated biphenyls. Anal. Chem. 2012, 84, 7648-7655. [CrossRef] [PubMed]

95. Rahmani, H.; Sajedi, R.H. Aequorin as a sensitive and selective reporter for detection of dopamine: A photoprotein inhibition assay approach. Int. J. Biol. Macromol. 2019, 122, 677-683. [CrossRef] [PubMed]

96. Rahmani, H.; Ghavamipour, F.; Sajedi, R.H. Bioluminescence detection of superoxide anion using aequorin. Anal. Chem. 2019, 91, 12768-12774. [CrossRef]

97. Dunstan, S.L.; Sala-Newby, G.B.; Fajardo, A.B.; Taylor, K.M.; Campbell, A.K. Cloning and expression of the bioluminescent photoprotein pholasin from the bivalve mollusc Pholas dactylus. J. Biol. Chem. 2000, 275, 9403-9409. [CrossRef]

98. Nourooz-Zadeh, J.; Ziegler, D.; Sohr, C.; Betteridge, J.D.; Knight, J.; Hothersall, J. The use of pholasin as a probe for the determination of plasma total antioxidant capacity. Clin. Biochem. 2006, 39, 55-61. [CrossRef]

99. Bryan, N.; Ashwin, H.; Smart, N.; Bayon, Y.; Scarborough, N.; Hunt, N. The innate oxygen dependent immune pathway as a sensitive parameter to predict the performance of biological graft materials. Biomaterials 2012, 33, 6380-6392. [CrossRef]

100. Bryan, N.; Ahswin, H.; Smart, N.J.; Bayon, Y.; Hunt, J.A. In vitro activation of human leukocytes in response to contact with synthetic hernia meshes. Clin. Biochem. 2012, 45, 672-676. [CrossRef]

101. Hunt, J.A.; Fok, M.; Bryan, N. Impact of cell purification technique of autologous human adult stem cells on inflammatory reaction. Biomaterials 2013, 34, 7626-7631. [CrossRef]

102. Shah, A.; Passacquale, G.; Gkaliagkousi, E.; Ritter, J.; Ferro, A. Platelet nitric oxide signalling in heart failure: Role of oxidative stress. Cardiovasc. Res. 2011, 91, 625-631. [CrossRef]

103. Farthing, D.E.; Sica, D.; Hindle, M.; Edinboro, L.; Xi, L.; Gehr, T.W.B.; Gehr, L.; Farthing, C.A.; Larus, T.L.; Fakhrya, I.; et al. A rapid and simple chemiluminescence method for screening levels of inosine and hypoxanthine in non-traumatic chest pain patients. Luminescence 2011, 26, 65-75. [CrossRef] [PubMed]

104. Hughes, D.L.; Richards, R.S.; Lexis, L.A. Using chemiluminescence to determine whole blood antioxidant capacity in rheumatoid arthritis and Parkinson's disease patients. Luminescence 2018, 33, 764-770. [CrossRef] [PubMed]

105. Lorenz, W.W.; McCann, R.O.; Longiaru, M.; Cormierm, M.J. Isolation and expression of a cDNA encoding Renilla reniformis luciferase. Proc. Natl. Acad. Sci. USA 1991, 88, 4438-4442. [CrossRef] [PubMed]

106. Markova, S.V.; Larionova, M.D.; Burakova, L.P.; Vysotski, E.S. The smallest natural high-active luciferase: Cloning and characterization of novel 16.5-kDa luciferase from copepod Metridia longa. Biochem. Biophys. Res. Commun. 2015, 457,77-82. [CrossRef]

107. Krasitskaya, V.V.; Burakova, L.P.; Pyshnaya, I.A.; Frank, L.A. Bioluminescent reporters for identification of gene allelic variants. Russ. J. Bioorg. Chem. 2012, 38, 298-305. [CrossRef]

108. Moutsiopoulou, A.; Hunt, E.; Broyles, D.; Pereira, C.A.; Woodward, K.; Dikici, E.; Kaifer, A.; Daunert, S.; Deo, S.K. Bioorthogonal protein conjugation: Application to the development of a highly sensitive bioluminescent immunoassay for the detection of interferon- $\gamma$. Bioconjugate Chem. 2017, 28, 1749-1757. [CrossRef]

109. Wouters, S.F.A.; Vugs, W.J.P.; Arts, R.; de Leeuw, N.M.; Teeuwen, R.W.H.; Merkx, M. Bioluminescent antibodies through photoconjugation of protein G-luciferase fusion proteins. Bioconjugate Chem. 2020, 31, 656-662. [CrossRef]

110. Loening, A.M.; Fenn, T.D.; Wu, A.M.; Gambhir, S.S. Consensus guided mutagenesis of Renilla luciferase yields enhanced stability and light output. Protein Eng. Des. Sel. 2006, 19, 391-400. [CrossRef]

111. Burakova, L.P.; Kudryavtsev, A.N.; Stepanyuk, G.A.; Baykov, I.K.; Morozova, V.V.; Tikunova, N.V.; Dubova, M.A.; Lyapustin, V.N.; Yakimenko, V.V.; Frank, L.A. Bioluminescent detection probe for tick-borne encephalitis virus immunoassay. Anal. Bioanal. Chem. 2015, 407, 5417-5423. [CrossRef]

112. Lu, Q.; Grotzke, J.E.; Cresswell, P. A novel probe to assess cytosolic entry of exogenous proteins. Nat. Commun. 2018, 9, 3104. [CrossRef]

113. Varnosfaderani, Z.G.; Emamzadeh, R.; Nazari, M.; Zarean, M. Detection of a prostate cancer cell line using a bioluminescent affiprobe: An attempt to develop a new molecular probe for ex vivo studies. Int. J. Biol. Macromol. 2019, 138, 755-763. [CrossRef] [PubMed]

114. Kim, M.A.; Yoon, H.S.; Park, S.H.; Kim, D.Y.; Pyo, A.; Kim, H.S.; Min, J.J.; Hong, Y. Engineering of monobody conjugates for human EphA2-specific optical imaging. PLoS ONE 2017, 12, e0180786. [CrossRef] [PubMed] 
115. Burbelo, P.D.; Lebovitz, E.E.; Notkins, A.L. Luciferase immunoprecipitation systems for measuring antibodies in autoimmune and infectious diseases. Transl. Res. 2015, 165, 325-335. [CrossRef] [PubMed]

116. Tin, C.M.; Yuan, L.; Dexter, R.J.; Parra, G.I.; Bui, T.; Green, K.Y.; Sosnovtsev, S.V. A luciferase immunoprecipitation system (LIPS) assay for profiling human norovirus antibodies. J. Virol. Methods 2017, 248, 116-129. [CrossRef]

117. Farkas, T.; Jäättelä, M. Renilla luciferase-LC3 based reporter assay for measuring autophagic flux. Methods Enzymol. 2017, 588, 1-13. [CrossRef]

118. Head, T.; Dau, P.; Duffort, S.; Daftarian, P.; Joshi, P.M.; Vazquez-Padron, R.; Deo, S.K.; Daunert, S. An enhanced bioluminescence-based Annexin V probe for apoptosis detection in vitro and in vivo. Cell Death Dis. 2017, 8, e2826. [CrossRef]

119. Farzannia, A.; Roghanian, R.; Zarkesh-Esfahani, S.H.; Nazari, M.; Emamzadeh, R. FcUni-RLuc: An engineered Renilla luciferase with Fc binding ability and light emission activity. Analyst 2015, 140, 1438-1441. [CrossRef]

120. Nazari, M.; Emamzadeh, R.; Hosseinkhani, S.; Cevenini, L.; Michelini, E.; Roda, A. Renilla luciferase-labeled Annexin V: A new probe for detection of apoptotic cells. Analyst 2012, 137, 5062-5070. [CrossRef]

121. Larionova, M.D.; Markova, S.V.; Tikunova, N.V.; Vysotski, E.S. The smallest isoform of Metridia longa luciferase as a fusion partner for hybrid proteins. Int. J. Mol. Sci. 2020, 21, 4971. [CrossRef]

122. De Leo, T.C.; Santos, S.N.D.; Andrade, C.D.C.; Ricci, E.; Turato, W.M.; Lopes, N.P.; Oliveira, R.S.; Bernardes, E.S.; Dias-Baruffi, M. Engineering of galectin-3 for glycan-binding optical imaging. Biochem. Biophys. Res. Commun. 2020, 521, 674-680. [CrossRef]

123. Weihs, F.; Peh, A.; Dacres, H. A red-shifted bioluminescence resonance energy transfer (BRET) biosensing system for rapid measurement of plasmin activity in human plasma. Anal. Chim. Acta 2020, 1102, 99-108. [CrossRef] [PubMed]

124. Tao, H.; Chen, X.; Wei, A.; Song, X.; Wang, W.; Liang, L.; Zhao, Q.; Han, Z.; Han, Z.; Wang, X.; et al. Comparison of teratoma formation between embryonic stem cells and parthenogenetic embryonic stem cells by molecular imaging. Stem. Cells Int. 2018, 2018, 7906531. [CrossRef] [PubMed]

125. Saw, W.T.; Matsuda, Z.; Eisenberg, R.J.; Cohen, G.H.; Atanasiu, D. Using a split luciferase assay (SLA) to measure the kinetics of cell-cell fusion mediated by herpes simplex virus glycoproteins. Methods 2015, 90, 68-75. [CrossRef] [PubMed]

126. Nakane, S.; Matsuda, Z. Dual split protein (DSP) assay to monitor cell-cell membrane fusion. Methods Mol. Biol. 2015, 1313, 229-236. [CrossRef]

127. Yamamoto, M.; Matsuyama, S.; Li, X.; Takeda, M.; Kawaguchi, Y.; Inoue, J.-I.; Matsuda, Z. Identification of nafamostat as a potent inhibitor of middle east respiratory syndrome coronavirus $\mathrm{S}$ protein-mediated membrane fusion using the split-protein-based cell-cell fusion assay. Antimicrob. Agents Chemother. 2016, 60, 6532-6539. [CrossRef]

128. Ashkenazi, S.; Plotnikov, A.; Bahat, A.; Dikstein, R. Effective cell-free drug screening protocol for protein-protein interaction. Anal. Biochem. 2017, 532, 53-59. [CrossRef]

129. Toribio, V.; Morales, S.; López-Martín, S.; Cardeñes, B.; Cabañas, C.; Yáñez-Mó, M. Development of a quantitative method to measure EV uptake. Sci. Rep. 2019, 9, 10522. [CrossRef]

130. Lund, C.H.; Bromley, J.R.; Stenbæk, A.; Rasmussen, R.E.; Scheller, H.V.; Sakuragi, Y. A reversible Renilla luciferase protein complementation assay for rapid identification of protein-protein interactions reveals the existence of an interaction network involved in xyloglucan biosynthesis in the plant Golgi apparatus. J. Exp. Bot. 2015, 66, 85-97. [CrossRef]

131. Wang, J.; Guo, W.; Long, C.; Zhou, H.; Wang, H.; Sun, X. The split Renilla luciferase complementation assay is useful for identifying the interaction of Epstein-Barr virus protein kinase BGLF4 and a heat shock protein Hsp90. Acta Virol. 2016, 60, 62-70. [CrossRef]

132. Varnum, M.M.; Clayton, K.A.; Yoshii-Kitahara, A.; Yonemoto, G.; Koro, L.; Ikezu, S.; Ikezu, T. A split-luciferase complementation, real-time reporting assay enables monitoring of the disease-associated transmembrane protein TREM2 in live cells. J. Biol. Chem. 2017, 292, 10651-10663. [CrossRef]

133. Siddiqui, F.A.; Parkkola, H.; Manoharan, G.B.; Abankwa, D. Medium-throughput detection of Hsp90/Cdc37 protein-protein interaction inhibitors using a split Renilla luciferase-based assay. SLAS Discov. 2020, 25, 195-206. [CrossRef] [PubMed]

134. Leng, W.; Li, D.; Chen, L.; Xia, H.; Tang, Q.; Chen, B.; Gong, Q.; Gao, F.; Bi, F. Novel Bioluminescent Activatable Reporter for Src Tyrosine Kinase Activity in Living Mice. Theranostics 2016, 6, 594-609. [CrossRef] [PubMed] 
135. Kim, S.B.; Ozawa, T.; Umezawa, Y. A genetically encoded bioluminescent indicator for illuminating proinflammatory cytokines. MethodsX 2016, 3, 483-489. [CrossRef] [PubMed]

136. Lin, J.; Hisaoka, M.; Nagata, K.; Okuwaki, M. Functional characterization and efficient detection of Nucleophosmin/NPM1 oligomers. Biochem. Biophys. Res. Commun. 2016, 480, 702-708. [CrossRef]

137. Paulmurugan, R.; Afjei, R.; Sekar, T.V.; Babikir, H.A.; Massoud, T.F. A protein folding molecular imaging biosensor monitors the effects of drugs that restore mutant $\mathrm{p} 53$ structure and its downstream function in glioblastoma cells. Oncotarget 2018, 9, 21495-21511. [CrossRef]

138. Kobayashi, H.; Picard, L.P.; Schönegge, A.M.; Bouvier, M. Bioluminescence resonance energy transfer-based imaging of protein-protein interactions in living cells. Nat. Protoc. 2019, 14, 1084-1107. [CrossRef]

139. Dimri, S.; Basu, S.; De, A. Use of BRET to study protein-protein interactions in vitro and in vivo. Methods Mol. Biol. 2016, 1443, 57-78. [CrossRef]

140. Strungs, E.G.; Luttrell, L.M.; Lee, M.H. Probing arrestin function using intramolecular FlAsH-BRET biosensors. Methods Mol. Biol. 2019, 1957, 309-322. [CrossRef]

141. Tsuboi, S.; Jin, T. Bioluminescence resonance energy transfer (BRET) coupled near-infrared imaging of apoptotic cells. Methods Mol. Biol. 2020, 2081, 15-27. [CrossRef]

142. Stumpf, C.; Wimmer, T.; Lorenz, B.; Stieger, K. Creation of different bioluminescence resonance energy transfer based biosensors with high affinity to VEGF. PLOS ONE 2020, 15, e0230344. [CrossRef]

143. Dacres, H.; Michie, M.; Wang, J.; Pfleger, K.D.; Trowell, S.C. Effect of enhanced Renilla luciferase and fluorescent protein variants on the Förster distance of bioluminescence resonance energy transfer (BRET). Biochem. Biophys. Res. Commun. 2012, 425, 625-629. [CrossRef] [PubMed]

144. Rathod, M.; Mal, A.; De, A. Reporter-based BRET sensors for measuring biological functions in vivo. Methods Mol. Biol. 2018, 1790, 51-74. [CrossRef] [PubMed]

145. Samanta, A.; Medintz, I.L. Bioluminescence-based energy transfer using semiconductor quantum dots as acceptors. Sensors 2020, 20, 2909. [CrossRef] [PubMed]

146. Song, J.; Zhang, J. Self-illumination of carbon dots by bioluminescence resonance energy transfer. Sci. Rep. 2019, 9, 13796. [CrossRef] [PubMed]

147. Nair, A.K.; Baier, L.J. Using luciferase reporter assays to identify functional variants at disease-associated loci. Methods Mol. Biol. 2018, 1706, 303-319. [CrossRef]

148. Kim, B.; Kim, H.M.; Kang, M.K.; Sohn, D.H.; Han, S.J. 5'-UTR and ORF elements, as well as the $3^{\prime}$-UTR regulate the translation of Cyclin. Biochem. Biophys. Res. Commun. 2020, 527, 968-973. [CrossRef] [PubMed]

149. Wang, L.; Zhou, L.; Hu, D.; Ge, X.; Guo, X.; Yang, H. Porcine reproductive and respiratory syndrome virus suppresses post-transcriptionally the protein expression of IFN- $\beta$ by upregulating cellular microRNAs in porcine alveolar macrophages in vitro. Exp. Ther. Med. 2018, 15, 115-126. [CrossRef]

150. Shen, Z.; Ye, G.; Deng, F.; Wang, G.; Cui, M.; Fang, L.; Xiao, S.; Fu, Z.F.; Peng, G. Structural basis for the inhibition of host gene expression by porcine epidemic diarrhea virus nsp1. J. Virol. 2018, 92, e01896-17. [CrossRef]

151. Eguchi, T.; Kubota, S.; Takigawa, M. Promoter analyses of CCN genes. Methods Mol. Biol. 2017, 1489, 177-185. [CrossRef]

152. Palavecino, C.E.; Carrasco-Véliz, N.; Quest, A.F.G.; Garrido, M.P.; Valenzuela-Valderrama, M. The $5^{\prime}$ untranslated region of the anti-apoptotic protein Survivin contains an inhibitory upstream AUG codon. Biochem. Biophys. Res. Commun. 2020, 526, 898-905. [CrossRef]

153. Ji, H.; Li, Y.; Liu, Z.; Tang, M.; Zou, L.; Su, F.; Zhang, Y.; Zhang, J.; Li, H.; Li, L.; et al. Quantitative evaluation of the transcriptional activity of steroid hormone receptor mutants and variants using a single vector with two reporters and a receptor expression cassette. Front. Endocrinol. 2020, 11, 167. [CrossRef] [PubMed]

154. Adams, P.P.; Flores Avile, C.; Jewett, M.W. A dual luciferase reporter system for B. burgdorferi measures transcriptional activity during tick-pathogen interactions. Front. Cell Infect. Microbiol. 2017, 7, 225. [CrossRef] [PubMed]

155. Inan, C.; Muratoglu, H.; Arif, B.M.; Demirbag, Z. Transcriptional analysis of the putative glycosyltransferase gene (amv248) of the Amsacta moorei entomopoxvirus. Virus. Res. 2018, 243, 25-30. [CrossRef] [PubMed]

156. Unal, H. Luciferase reporter assay for unlocking ligand-mediated signaling of GPCRs. Methods Cell Biol. 2019, 149, 1930. [CrossRef]

157. Zheng, H.; Wang, X.; Chen, S.; Shi, X.; Xie, J.; Mao, W.; Tian, J.; Wang, F. Real-time functional bioimaging of neuron-specific microRNA dynamics during neuronal differentiation using a dual luciferase reporter. ACS Chem. Neurosci. 2019, 10, 1696-1705. [CrossRef] [PubMed] 
158. Dai, C.Y.; Tsai, Y.S.; Chou, W.W.; Liu, T.; Huang, C.F.; Wang, S.C.; Tsai, P.C.; Yeh, M.L.; Hsieh, M.Y.; Huang, C.I.; et al. The IL-6/STAT3 pathway upregulates microRNA-125b expression in hepatitis C virus infection. Oncotarget 2018, 9, 11291-11302. [CrossRef] [PubMed]

159. Wang, M.; Wang, W.; Wang, J.; Zhang, J. MiR-182 promotes glucose metabolism by upregulating hypoxia-inducible factor $1 \alpha$ in NSCLC cells. Biochem. Biophys. Res. Commun. 2018, 504, 400-405. [CrossRef]

160. Zheng, H.; Chen, S.; Wang, X.; Xie, J.; Tian, J.; Wang, F. Intron retained bioluminescence reporter for real-time imaging of pre-mRNA splicing in living subjects. Anal. Chem. 2019, 91, 12392-12398. [CrossRef]

161. Salani, M.; Urbina, F.; Brenner, A.; Morini, E.; Shetty, R.; Gallagher, C.S.; Law, E.A.; Sunshine, S.; Finneran, D.J.; Johnson, G.; et al. Development of a screening platform to identify small molecules that modify ELP1 pre-mRNA splicing in familial dysautonomia. SLAS Discov. 2019, 24, 57-67. [CrossRef]

162. Cao, D.; Ni, Y.Y.; Walker, M.; Huang, Y.W.; Meng, X.J. Roles of the genomic sequence surrounding the stem-loop structure in the junction region including the $3^{\prime}$ terminus of open reading frame 1 in hepatitis $\mathrm{E}$ virus replication. J. Med. Virol. 2018, 90, 1524-1531. [CrossRef]

163. Chen, S.; He, Y.; Zhang, R.; Liu, P.; Yang, C.; Wu, Z.; Zhang, J.; Wang, M.; Jia, R.; Zhu, D.; et al. Establishment of a reverse genetics system for duck Tembusu virus to study virulence and screen antiviral genes. Antiviral. Res. 2018, 157, 120-127. [CrossRef] [PubMed]

164. Cao, D.; Ni, Y.Y.; Meng, X.J. Substitution of amino acid residue V1213 in the helicase domain of the genotype 3 hepatitis E virus reduces virus replication. Virol. J. 2018, 15, 32. [CrossRef] [PubMed]

165. Xie, W.; Silvers, R.; Ouellette, M.; Wu, Z.; Lu, Q.; Li, H.; Gallagher, K.; Johnson, K.; Montoute, M. A luciferase reporter gene system for high-throughput screening of $\gamma$-globin gene activators. Methods Mol. Biol. 2016, 1439, 207-226. [CrossRef] [PubMed]

166. Feng, L.; Lu, W.; Ma, Y.; Guo, W.; Wang, Y.; Sun, Q.; Wu, J.; Zhao, G.; Zhang, X. A novel dual-luciferase assay for anti-HIV drug screening based on the CCR5/CXCR4 promoters. J. Virol. Methods 2018, 256, 17-23. [CrossRef]

167. Lang, Y.; Li, Y.; Jasperson, D.; Henningson, J.; Lee, J.; Ma, J.; Li, Y.; Duff, M.; Liu, H.; Bai, D.; et al. Identification and evaluation of antivirals for Rift Valley fever virus. Vet. Microbiol. 2019, 230, 110-116. [CrossRef]

168. Shen, L.; Niu, J.; Wang, C.; Huang, B.; Wang, W.; Zhu, N.; Deng, Y.; Wang, H.; Ye, F.; Cen, S.; et al. High-throughput screening and identification of potent broad-spectrum inhibitors of coronaviruses. J. Virol. 2019, 93, e00023-19. [CrossRef]

169. Zhang, K.; Wang, C.; Wang, R.; Chen, S.; Li, Z. Dual bioluminescence imaging of tumor progression and angiogenesis. J. Vis. Exp. 2019, 150, e59763. [CrossRef]

170. Gangadaran, P.; Ahn, B.C. In vivo tracking of tumor-derived bioluminescent extracellular vesicles in mice. Methods Mol. Biol. 2020, 2081, 203-210. [CrossRef]

171. Niu, J.; Shen, L.; Huang, B.; Ye, F.; Zhao, L.; Wang, H.; Deng, Y.; Tan, W. Non-invasive bioluminescence imaging of HCoV-OC43 infection and therapy in the central nervous system of live mice. Antiviral. Res. 2020, 173, 104646. [CrossRef]

172. Dou, L.; Matz, E.L.; Gu, X.; Shu, F.; Paxton, J.; Song, J.; Yoo, J.; Atala, A.; Jackson, J.; Zhang, Y. Non-invasive cell tracking with brighter and red-transferred luciferase for potential application in stem cell therapy. Cell Transplant. 2019, 28, 1542-1551. [CrossRef]

173. Jiang, Y.; Lu, Q.; Wang, Y.; Xu, E.; Ho, A.; Singh, P.; Wang, Y.; Jiang, Z.; Yang, F.; Tietjen, G.T.; et al. Quantitating endosomal escape of a library of polymers for mRNA delivery. Nano Lett. 2020, 20, 1117-1123. [CrossRef] [PubMed]

174. Markova, S.V.; Larionova, M.D.; Vysotski, E.S. Shining light on the secreted luciferases of marine copepods: Current knowledge and applications. Photochem. Photobiol. 2019, 95, 705-721. [CrossRef] [PubMed]

175. England, C.G.; Ehlerding, E.B.; Cai, W. NanoLuc: A small luciferase is brightening up the field of bioluminescence. Bioconjugate Chem. 2016, 27, 1175-1187. [CrossRef] [PubMed]

176. Soave, M.; Heukers, R.; Kellam, B.; Woolard, J.; Smit, M.J.; Briddon, S.J.; Hill1, S.J. Monitoring allosteric interactions with CXCR4 using NanoBiT conjugated nanobodies. Cell Chem. Biol. 2020, 27, 1-12. [CrossRef]

177. Soave, M.; Kellam, B.; Woolard, J.; Briddon, S.J.; Hill, S.J. NanoBiT Complementation to monitor agonist-induced adenosine $\mathrm{A}_{1}$ receptor internalization. SLAS Discov. 2020, 25, 186-194. [CrossRef] [PubMed]

178. Cooley, R.; Kara, N.; Hui, N.S.; Tart, J.; Roustan, C.; George, R.; Hancock, D.C.; Binkowski, B.F.; Wood, K.V.; Ismail, M. Development of a cell-free split-luciferase biochemical assay as a tool for screening for inhibitors of challenging protein-protein interaction targets. Wellcome Open Res. 2020, 5, 20. [CrossRef] 
179. Le Boulch, M.; Brossard, A.; Le Dez, G.; Leon, S.; Rabut, G. Sensitive detection of protein ubiquitylation using a protein fragment complementation assay. J. Cell Sci. 2020, 133, jcs240093. [CrossRef]

180. Nouri, K.; Azad, T.; Ling, M.; Janse van Rensburg, H.J.; Pipchuk, A.; Shen, H.; Hao, Y.; Zhang, J.; Yang, X. Identification of celastrol as a novel YAP-TEAD inhibitor for cancer therapy by high throughput screening with ultrasensitive YAP/TAZ-TEAD biosensors. Cancers 2019, 11, 1596. [CrossRef]

181. Machleidt, T.; Woodroofe, C.C.; Schwinn, M.K.; Méndez, J.; Robers, M.B.; Zimmerman, K.; Otto, P.; Daniels, D.L.; Kirkland, T.A.; Wood, K.V. NanoBRET-A novel BRET platform for the analysis of protein-protein interactions. ACS Chem. Biol. 2015, 10, 1797-1804. [CrossRef]

182. Mo, X.L.; Luo, Y.; Ivanov, A.A.; Su, R.; Havel, J.J.; Li, Z.; Khuri, F.R.; Du, Y.; Fu, H. Enabling systematic interrogation of protein-protein interactions in live cells with a versatile ultra-high-throughput biosensor platform. J. Mol. Cell Biol. 2016, 8, 271-281. [CrossRef]

183. Boursier, M.E.; Levin, S.; Zimmerman, K.; Machleidt, T.; Hurst, R.; Butler, B.L.; Eggers, C.T.; Kirkland, T.A.; Wood, K.V.; Friedman Ohana, R. The luminescent HiBiT peptide enables selective quantitation of G protein-coupled receptor ligand engagement and internalization in living cells. J. Biol. Chem. 2020, 295, 5124-5135. [CrossRef] [PubMed]

184. Phillipou, A.N.; Lay, C.S.; Carver, C.E.; Messenger, C.; Evans, J.P.; Lewis, A.J.; Gordon, L.J.; Mahmood, M.; Greenhough, L.A.; Sammon, D.; et al. Cellular target engagement approaches to monitor epigenetic reader domain interactions. SLAS Discov. 2020, 25, 163-175. [CrossRef] [PubMed]

185. Wang, J.H.; Shao, X.X.; Hu, M.J.; Wei, D.; Liu, Y.L.; Xu, Z.G.; Guo, Z.Y. A novel BRET-based binding assay for interaction studies of relaxin family peptide receptor 3 with its ligands. Amino Acids 2017, 49, 895-903. [CrossRef] [PubMed]

186. Oishi, A.; Dam, J.; Jockers, R. $\beta$-Arrestin-2 BRET biosensors detect different $\beta$-Arrestin- 2 conformations in interaction with GPCRs. ACS Sens. 2020, 5, 57-64. [CrossRef]

187. Den Hamer, A.; Dierickx, P.; Arts, R.; de Vries, J.S.P.M.; Brunsveld, L.; Merkx, M. Bright bioluminescent BRET sensor proteins for measuring intracellular Caspase activity. ACS Sens. 2017, 2, 729-734. [CrossRef]

188. Min, S.H.; French, A.R.; Trull, K.J.; Tat, K.; Varney, S.A.; Tantama, M. Ratiometric BRET measurements of ATP with a genetically-encoded luminescent sensor. Sensors 2019, 19, 3502. [CrossRef]

189. Hoare, B.L.; Kocan, M.; Bruell, S.; Scott, D.J.; Bathgate, R.A.D. Using the novel HiBiT tag to label cell surface relaxin receptors for BRET proximity analysis. Pharmacol. Res. Perspect. 2019, 7, e00513. [CrossRef]

190. Dimri, S.; Arora, R.; Jasani, A.; De, A. Dynamic monitoring of STAT3 activation in live cells using a novel STAT3 phospho-BRET sensor. Am. J. Nucl. Med. Mol. Imaging 2019, 9, 321334.

191. Stoddart, L.A.; Vernall, A.J.; Bouzo-Lorenzo, M.; Bosma, R.; Kooistra, A.J.; de Graaf, C.; Vischer, H.F.; Leurs, R.; Briddon, S.J.; Kellam, B.; et al. Development of novel fluorescent histamine H 1-receptor antagonists to study ligand-binding kinetics in living cells. Sci. Rep. 2018, 8, 1572. [CrossRef]

192. Hiblot, J.; Yu, Q.; Sabbadini, M.D.; Reymond, L.; Xue, L.; Schena, A.; Sallin, O.; Hill, N.; Griss, R.; Johnsson, K. Luciferases with tunable emission wavelengths. Angew. Chem. Int. Ed. 2017, 129, 14748-14752. [CrossRef]

193. Kilpatrick, L.E.; Friedman-Ohana, R.; Alcobia, D.C.; Riching, K.; Peach, C.J.; Wheal, A.J.; Briddon, S.J.; Robers, M.B.; Zimmerman, K.; Machleidt, T.; et al. Real-time analysis of the binding of fluorescent VEGF165a to VEGFR2 in living cells: Effect of receptor tyrosine kinase inhibitors and fate of internalized agonist-receptor complexes. Biochem. Pharmacol. 2017, 136, 62-75. [CrossRef] [PubMed]

194. Christiansen, E.; Hudson, B.D.; Hansen, A.H.; Milligan, G.; Ulven, T. Development and characterization of a potent free fatty acid receptor 1 (FFA1) fluorescent tracer. J. Med. Chem. 2016, 59, 4849-4858. [CrossRef] [PubMed]

195. Thirukkumaran, O.M.; Wang, C.; Asouzu, N.J.; Fron, E.; Rocha, S.; Hofkens, J.; Lavis, L.D.; Mizuno, H. Improved HaloTag ligand enables BRET imaging with NanoLuc. Front. Chem. 2020, 7, 938. [CrossRef] [PubMed]

196. Los, G.V.; Encell, L.P.; McDougall, M.G.; Hartzell, D.D.; Karassina, N.; Zimprich, C.; Wood, M.G.; Learish, R.; Ohana, R.F.; Urh, M.; et al. HaloTag: A novel protein labeling technology for cell imaging and protein analysis. ACS Chem. Biol. 2008, 3, 373-382. [CrossRef] [PubMed]

197. Stoddart, L.A.; Kilpatrick, L.E.; Hill, S.J. NanoBRET approaches to study ligand binding to GPCRs and RTKs. Trends Pharmacol. Sci. 2017, 39, 136-147. [CrossRef] [PubMed]

198. Dale, N.C.; Johnstone, E.K.M.; White, C.W.; Pfleger, K.D.G. NanoBRET: The bright future of proximity-based assays. Front. Bioeng. Biotechnol. 2019, 7, 56. [CrossRef] [PubMed] 
199. Park, I.S.; Seo, H.R.; Kim, K.; Lee, H.; Shum, D.; Choi, I.; Kim, J. Identification of inhibitors of Bcl-2 family protein-protein interaction by combining the BRET screening platform with virtual screening. Biochem. Biophys. Res. Commun. 2020, 527, 709715. [CrossRef]

200. Mocking, T.A.M.; Buzink, M.C.M.L.; Leurs, R.; Vischer, H.F. Bioluminescence resonance energy transfer based $\mathrm{G}$ protein-activation assay to probe duration of antagonism at the histamine $\mathrm{H} 3$ receptor. Int. J. Mol Sci. 2019, 20, 3724. [CrossRef]

201. Kilpatrick, L.E.; Alcobia, D.C.; White, C.W.; Peach, C.J.; Glenn, J.R.; Zimmerman, K.; Kondrashov, A.; Pfleger, K.D.G.; Ohana, R.F.; Robers, M.B.; et al. Complex formation between VEGFR2 and the ß2-Adrenoceptor. Cell Chem. Biol. 2019, 26, 830-841. [CrossRef]

202. Lanznaster, D.; Massari, C.M.; Marková, V.; Šimková, T.; Duroux, R.; Jacobson, K.A.; Fernández-Dueñas, V.; Tasca, C.I.; Ciruela, F. Adenosine A1-A2A receptor-receptor interaction: Contribution to guanosine-mediated effects. Cells 2019, 8, 1630. [CrossRef]

203. Friedman Ohana, R.; Hurst, R.; Rosenblatt, M.; Levin, S.; Machleidt, T.; Kirkland, T.A.; Encell, L.P.; Robers, M.B.; Wood, K.V. Utilizing a simple method for stoichiometric protein labeling to quantify antibody blockade. Sci. Rep. 2019, 9, 7046. [CrossRef] [PubMed]

204. Ong, T.T.; Ang, Z.; Verma, R.; Koean, R.; Kit Chung Tam, J.; Ling Ding, J. pHLuc, a ratiometric luminescent reporter for in vivo monitoring of tumor acidosis. Front. Bioeng. Biotechnol. 2020, 8, 412. [CrossRef] [PubMed]

205. Taylor, A.; Sharkey, J.; Plagge, A.; Wilm, B.; Murray, P. Multicolour in vivo bioluminescence imaging using a NanoLuc-based BRET reporter in combination with firefly luciferase. Contrast Media. Mol. Imaging 2018, 2018, 1-10. [CrossRef] [PubMed]

206. Kamkaew, A.; Sun, H.; England, C.G.; Cheng, L.; Liu, Z.; Cai, W. Quantum dot-NanoLuc bioluminescence resonance energy transfer enables tumor imaging and lymph node mapping in vivo. Chem. Commun. 2016, 52, 6997-7000. [CrossRef]

207. Shakhmin, A.; Hall, M.P.; Machleidt, T.; Walker, J.R.; Wood, K.V.; Kirkland, T.A. Coelenterazine analogues emit red-shifted bioluminescence with NanoLuc. Org. Biomol. Chem. 2017, 15, 8559-8567. [CrossRef]

208. Yeh, H.W.; Karmach, O.; Ji, A.; Carter, D.; Martins-Green, M.M.; Ai, H.W. Red-shifted luciferase-luciferin pairs for enhanced bioluminescence imaging. Nat. Methods 2017, 14, 971-974. [CrossRef]

209. Nishihara, R.; Hoshino, E.; Kakudate, Y.; Kishigami, S.; Iwasawa, N.; Sasaki, S.I.; Nakajima, T.; Sato, M.; Nishiyama, S.; Citterio, D.; et al. Azide- and Dye-conjugated coelenterazine analogues for a multiplex molecular imaging platform. Bioconjugate Chem. 2018, 29, 1922-1931. [CrossRef]

210. Yang, J.; Cumberbatch, D.; Centanni, S.; Shi, S.Q.; Winder, D.; Webb, D.; Johnson, C.H. Coupling optogenetic stimulation with NanoLuc-based luminescence (BRET) $\mathrm{Ca}^{2+}$ sensing. Nat. Commun. 2016, 7, 13268. [CrossRef]

211. Qian, Y.; Rancic, V.; Wu, J.; Ballanyi, K.; Campbell, R.E. A Bioluminescent $\mathrm{Ca}^{2+}$ indicator based on a topological variant of GCaMP6s. ChemBioChem 2019, 20, 516-520. [CrossRef]

212. Arts, R.; Aper, S.J.A.; Merkx, M. Engineering BRET-sensor proteins. Methods Enzymol. 2017, 589, 87-114. [CrossRef]

213. Arts, R.; Ludwig, S.K.J.; van Gerven, B.C.B.; Estirado, E.M.; Milroy, L.G.; Merkx, M. Semisynthetic bioluminescent sensor proteins for direct detection of antibodies and small molecules in solution. ACS Sens. 2017, 2, 1730-1736. [CrossRef] [PubMed]

214. Tenda, K.; van Gerven, B.; Arts, R.; Hiruta, Y.; Merkx, M.; Citterio, D. Paper-based antibody detection devices using bioluminescent BRET-switching sensor proteins. Angew. Chem. Int. Ed. Engl. 2018, 57, 15369-15373. [CrossRef] [PubMed]

215. Arts, R.; den Hartog, I.; Zijlema, S.E.; Thijssen, V.; van der Beelen, S.H.E.; Merkx, M. Detection of antibodies in blood plasma using bioluminescent sensor proteins and a smartphone. Anal. Chem. 2016, 88, 4525-4532. [CrossRef] [PubMed]

216. Xue, L.; Yu, Q.; Griss, R.; Schena, A.; Johnsson, K. Bioluminescent antibodies for point-of-care diagnostics. Angew. Chem. Int. Ed. Engl. 2017, 56, 7112-7116. [CrossRef]

217. Engelen, W.; van de Wiel, K.M.; Meijer, L.H.H.; Saha, B.; Merkx, M. Nucleic acid detection using BRET-beacons based on bioluminescent protein-DNA hybrids. Chem. Commun. 2017, 53, 2862-2865. [CrossRef]

218. Shigeto, H.; Ikeda, T.; Kuroda, A.; Funabashi, H. A BRET-based homogeneous insulin assay using interacting domains in the primary binding site of the insulin receptor. Anal. Chem. 2015, 87, 2764-2770. [CrossRef]

219. Ren, W.; Li, Z.; Xu, Y.; Wan, D.; Barnych, B.; Li, Y.; Tu, Z.; He, Q.; Fu, J.; Hammock, B.D. One-Step ultrasensitive bioluminescent enzyme immunoassay based on Nanobody/Nanoluciferase fusion for detection of aflatoxin B1 in cereal. J. Agric. Food Chem. 2019, 67, 5221-5229. [CrossRef] 
220. Wang, H.; Cai, Q.; Liang, Y.; Shui, J.; Tang, S. A simple and high-throughput luciferase immunosorbent assay for both qualitative and semi-quantitative detection of anti-HIV-1 antibodies. Virus Res. 2019, 263, 9-15. [CrossRef]

221. Tin, C.M.; Sosnovtsev, S.V. Detection of human norovirus-specific antibodies using the luciferase immunoprecipitation system (LIPS). Methods Mol. Biol. 2019, 2024, 137-152. [CrossRef]

222. Ling, Y.; Jiang, P.; Li, N.; Yan, Q.; Wang, X. A luciferase immunoprecipitation assay for the detection of proinsulin/insulin autoantibodies. Clin. Biochem. 2018, 54, 51-55. [CrossRef]

223. Hui, J.Z.; Tamsen, S.; Song, Y.; Tsourkas, A. LASIC: Light activated site-specific conjugation of native IgGs. Bioconjugate Chem. 2015, 26, 1456-1460. [CrossRef] [PubMed]

224. Ikeda, Y.; Mashimo, Y.; Mie, M.; Kobatake, E. Design of luciferase-displaying protein nanoparticles for use as highly sensitive immunoassay detection probes. Analyst 2016, 141, 6557-6563. [CrossRef] [PubMed]

225. Mie, M.; Niimi, T.; Mashimo, Y.; Kobatake, E. Construction of DNA-NanoLuc luciferase conjugates for DNA aptamer-based sandwich assay using Rep protein. Biotechnol. Lett. 2019, 41, 357-362. [CrossRef] [PubMed]

226. Hinkley, T.C.; Garing, S.; Singh, S.; Le Ny, A.M.; Nichols, K.P.; Peters, J.E.; Talbert, J.N.; Nugen, S.R. Reporter bacteriophage T7 NLC utilizes a novel NanoLuc: CBM fusion for the ultrasensitive detection of Escherichia coli in water. Analyst 2018, 143, 4074-4082. [CrossRef] [PubMed]

227. Kozak, S.; Alcaine, S.D. Phage-based forensic tool for spatial visualization of bacterial contaminants in cheese. J. Dairy Sci. 2020, 103, 5964-5971. [CrossRef] [PubMed]

228. Ohmuro-Matsuyama, Y.; Chung, C.I.; Ueda, H. Demonstration of protein-fragment complementation assay using purified firefly luciferase fragments. BMC Biotechnol. 2013, 13, 31. [CrossRef]

229. Ohmuro-Matsuyama, Y.; Ueda, H. Homogeneous noncompetitive luminescent immunodetection of small molecules by ternary protein fragment complementation. Anal. Chem. 2018, 90, 3001-3004. [CrossRef]

230. Ranawakage, D.C.; Takada, T.; Kamachi, Y. HiBiT-qIP, HiBiT-based quantitative immunoprecipitation, facilitates the determination of antibody affinity under immunoprecipitation conditions. Sci. Rep. 2019, 9, 6895. [CrossRef]

231. Tetsuo, M.; Matsuno, K.; Tamura, T.; Fukuhara, T.; Kim, T.; Okamatsu, M.; Tautz, N.; Matsuura, Y.; Sakoda, Y. Development of a high-throughput serum neutralization test using recombinant pestiviruses possessing a small reporter tag. Pathogens 2020, 9, 188. [CrossRef]

232. Tran, V.; Moser, L.A.; Poole, D.S.; Mehle, A. Highly sensitive real-time in vivo imaging of an influenza reporter virus reveals dynamics of replication and spread. J. Virol. 2013, 87, 13321-13329. [CrossRef]

233. Karlsson, E.A.; Meliopoulos, V.A.; Savage, C.; Livingston, B.; Mehle, A.; Schultz-Cherry, S. Visualizing real-time influenza virus infection, transmission and protection in ferrets. Nat. Commun. 2015, 6, 6378. [CrossRef] [PubMed]

234. Cai, H.; Liu, M.; Russell, C.J. Directed evolution of an influenza reporter virus to restore replication and virulence and enhance non-invasive bioluminescence imaging in mice. J. Virol. 2018, e00593-18. [CrossRef]

235. Chiem, K.; Rangel-Moreno, J.; Nogales, A.; Martinez-Sobrido, L. A Luciferase-fluorescent reporter influenza virus for live imaging and quantification of viral infection. J. Vis. Exp. 2019, 150, e59890. [CrossRef] [PubMed]

236. Nogales, A.; Ávila-Pérez, G.; Rangel-Moreno, J.; Chiem, K.; DeDiego, M.L.; Martínez-Sobrido, L. A novel fluorescent and bioluminescent Bireporter influenza A virus to evaluate viral infections. J. Virol. 2019, 93, e0032-19. [CrossRef] [PubMed]

237. Nishitsuji, H.; Harada, K.; Ujino, S.; Zhang, J.; Kohara, M.; Sugiyama, M.; Mizokami, M.; Shimotohno, K. Investigating the hepatitis B virus life cycle using engineered reporter hepatitis B viruses. Cancer Sci. 2018, 109, 241-249. [CrossRef] [PubMed]

238. Harada, K.; Nishitsuji, H.; Ujino, S.; Shimotohno, K. Identification of KX2-391 as an inhibitor of HBV transcription by a recombinant HBV-based screening assay. Antiviral Res. 2017, 144, 138-146. [CrossRef]

239. Ruan, J.; Ping, C.Y.; Sun, S.; Cheng, X.; Han, P.Y.; Zhang, Y.G.; Sun, D.X. Construction of a replication-competent hepatitis $B$ virus vector carrying secreted luciferase transgene and establishment of new hepatitis $B$ virus replication and expression cell lines. World J. Gastroenterol. 2019, 25, 5961-5972. [CrossRef]

240. Szkolnicka, D.; Pollán, A.; da Silva, N.; Oechslin, N.; Gouttenoire, J.; Moradpour, D. Recombinant Hepatitis E Viruses harboring tags in the ORF1 protein. J. Virol. 2019, 93, e00459-19. [CrossRef]

241. Kirui, J.; Freed, E.O. Generation and validation of a highly sensitive bioluminescent HIV1 reporter vector that simplifies measurement of virus release. Retrovirology 2020, 17. [CrossRef]

242. Kanai, Y.; Kawagishi, T.; Nouda, R.; Onishi, M.; Pannacha, P.; Nurdin, J.A.; Nomura, K.; Matsuura, Y.; Kobayashia, T. Development of 1 stable rotavirus reporter expression systems. J. Virol. 2019, 93, e01774-18. [CrossRef] 
243. Michihito, S.; Anindita, P.D.; Wallaya, P.; Michael, C.; Kobayashi, S.; Yasuko, O.; Hirofumi, S. Development of a rapid and quantitative method for the analysis of viral entry and release using a NanoLuc luciferase complementation assay. Virus Res. 2018, 243, 69-74. [CrossRef]

244. Tamura, T.; Igarashi, M.; Enkhbold, B.; Suzuki, T.; Okamatsu, M.; Ono, C.; Mori, H.; Izumi, T.; Sato, A.; Fauzyah, Y.; et al. In vivo dynamics of reporter Flaviviridae viruses. J. Virol. 2019, 93, e01191-19. [CrossRef] [PubMed]

245. Yun, S.I.; Song, B.H.; Woolley, M.E.; Frank, J.C.; Julander, J.G.; Lee, Y.M. Development, characterization, and application of two reporter-expressing recombinant Zika viruses. Viruses 2020, 12, 572. [CrossRef] [PubMed]

246. Belarbi, E.; Legros, V.; Basset, J.; Despres, P.; Roques, P.; Choumet, V. Bioluminescent ross river virus allows live monitoring of acute and long-term alphaviral infection by in vivo imaging. Viruses 2019, 11, 584. [CrossRef] [PubMed]

247. Oh-hashi, K.; Furuta, E.; Norisada, J.; Amaya, F.; Hirata, Y.; Kiuchi, K. Application of NanoLuc to monitor the intrinsic promoter activity of GRP78 using the CRISPR/Cas9 system. Genes Cells 2016, 21, 1137-1143. [CrossRef] [PubMed]

248. Basu, S.; Adams, L.; Guhathakurta, S.; Kim, Y.S. A novel tool for monitoring endogenous alpha-synuclein transcription by NanoLuciferase tag insertion at the $3^{\prime}$ end using CRISPR-Cas9 genome editing technique. Sci. Rep. 2017, 8, 45883. [CrossRef]

249. Lackner, D.H.; Carré, A.; Guzzardo, P.M.; Banning, C.; Mangena, R.; Henley, T.; Oberndorfer, S.; Gapp, B.V.; Nijman, S.M.B.; Brummelkamp, T.R.; et al. A generic strategy for CRISPR-Cas9-mediated gene tagging. Nat. Commun. 2015, 6, 10237. [CrossRef]

250. Campbell, L.A.; Richie, C.T.; Zhang, Y.; Heathward, E.J.; Coke, L.M.; Park, E.Y.; Harvey, B.K. In vitro modeling of HIV proviral activity in microglia. FEBS J. 2017, 284, 4096-4114. [CrossRef]

251. Schwinn, M.K.; Machleidt, T.; Zimmerman, K.; Eggers, C.T.; Dixon, A.S.; Hurst, R.; Hall, M.P.; Encell, L.P.; Binkowski, B.F.; Wood, K.V. CRISPR-mediated tagging of endogenous proteins with a luminescent peptide. ACS Chem. Biol. 2018, 13, 467-474. [CrossRef]

252. Grooms, K. Improving SARS-CoV-2 antibody detection with bioluminescence. Available online: https://www. promegaconnections.com/improving-sars-cov-2-antibody-detection-with-bioluminescence/ (accessed on 11 August 2020).

(C) 2020 by the authors. Licensee MDPI, Basel, Switzerland. This article is an open access article distributed under the terms and conditions of the Creative Commons Attribution (CC BY) license (http://creativecommons.org/licenses/by/4.0/). 